\title{
Corporate Scandals and Capital Structure
}

\author{
Stefano Bonini* \\ Bocconi University, \\ Via Roentgen 1, 20122, Milan, Italy \\ stefano.bonini@unibocconi.it \\ Diana Boraschi \\ Bocconi University, \\ Via Roentgen 1, 20122, Milan, Italy \\ diana.boraschi@unibocconi.it
}

First draft: May 2009

This draft: December 2010

JEL Codes: G32, G33, K41

Keywords: corporate scandals, security offerings, capital structure, contagion effect, market timing.

Acknowledgement: We thank Julian Franks, Matthew Pritsker, Alexander Dyck, Luigi Zingales, seminar participants at the NYU Pollack Center for Law and Business, International Risk Management Conference 2009, Law, Ethics and Finance Conference, International Corporate Finance and Governance Conference, Eurofidai-AFFI Paris Finance Meeting for helpful comments and suggestions. We are particularly indebted with Jeffrey Wurgler and Yakov Amihud for invaluable suggestions and support. We gratefully acknowledge Cornerstone Research support for providing security class action data. This paper has been developed while Stefano Bonini was Visiting Associate Professor at NYU Stern The ideas expressed in the paper do not necessarily reflect those of the authors' affiliations. Any errors remain our own. *Corresponding author 


\begin{abstract}
We analyze whether companies involved in a security class action suit (SCAS) exhibit differential capital structure decisions, and if the information revealed by a corporate scandal affects the security issuances and stock prices of industry peers. Our findings show that before a SCAS is filed, companies involved in a scandal show a greater amount of security offerings and, due to equity mispricing, are more likely to use equity as a financing mechanism. Following the SCAS filing, they exhibit decreasing amount of total external finance raised and lower levels of book and market leverage. Industry peers' issuance patterns exhibit significant contagion, with reduced debt and equity issuance following the SCAS filing. Corporate scandals have also meaningful negative effects on stock prices and bond ratings. Similarly to capital structure, we document contagion at the industry level with peers' share prices yielding negative returns as well.
\end{abstract}




\section{Introduction}

Another wave of corporate scandals has hit the market in the last decade, reviving attention to the effects of these events on shareholder value, corporate governance and stock market reactions. Academic research has shown that companies suffer a considerable decline in both stock prices and debt ratings upon Chapter 11 filing announcements, financial report restating or financial distress announcements (Palmrose, Richardson and Scholz, 2004; Lang and Stulz, 1992; Brewer and Jackson, 1997). The early detection of scandals, if not their prevention, is therefore valuable to stakeholders. Agrawal and Chadha (2005) document that appropriate corporate governance mechanisms may positively influence the probability of earnings restatements. Agrawal and Cooper (2007) support this evidence, highlighting the higher turnover of top management and top financial officers soon before and immediately after an accounting scandal. Dyck, Morse and Zingales (2010) show that non-traditional mechanisms and stakeholders-at-large play a considerable role in triggering fraud detection. Given the documented far-reaching effects of corporate scandals, we ask whether managerial behavior in companies engaged in a corporate scandal also affects financial decisions regarding capital raising, and in particular, whether managers anticipating the risks of a corporate scandal exhibit different capital structure policies than those of their peers. Surprisingly, though, this question is still unanswered. In this paper, we try to fill this gap by looking at the security issuance patterns of companies engaged in Security Class Action Suits (SCAS) between 1996 and 2005. In particular, we address three main research questions:

(a) What is the ex-ante and ex-post financing pattern of firms engaged in a corporate scandal?;

(b) Do corporate scandals affect the price and quality of the company's financial securities?

(c) Is there a contagion effect in the capital structure and stock prices of the industry after a corporate scandal is revealed?

Previous literature has addressed corporate scandals by studying cases of bankruptcy announcement, the public announcement of fraud in the press and earnings restatements. In this paper, we adopt engagement in a security class action suit as a proxy of a corporate scandal. We collect data from the Stanford Securities Class Action Clearinghouse (SSCAC) database ${ }^{1}$. This measure of corporate scandals allow us

\footnotetext{
${ }^{1}$ Database is mantained in cooperation with Cornerstone Research.
} 
to generalize the results to a broader set of cases because it deals with actions that a) are important enough to have permanent effects on security-holders value and b) leave the company as a going concern, allowing meaningful ex-ante and ex-post differential analysis. In fact, less than $7 \%$ of cases included in the SSCAC database end up with a bankruptcy filing.

Our findings show that before a SCAS is filed, companies engaged in a scandal have a higher number of security offerings than the industry average. At the same time, we document that because firms before the scandals experienced stock prices overvaluation, they were more likely to use equity as a financing mechanism. Compared to their peers, firms involved in a security class action consistently issued more equity in the two-year period preceding the filing of the suit. Consistent with market timing, we find that SCAS firms exhibit decreasing book and market leverage before the filing due to abnormal volumes of equity offerings. Soon after the filing, though, market leverage increases sharply and significantly due to the readjustment in equity market value. Industry peers are also affected by the eruption of a scandal. Following a SCAS filing, we observe smaller but significant decreases in debt and equity issuances also for peer companies which indicates that company-specific information is interpreted as a potential industry-wide risk.

Finally, we investigate the effect of corporate scandals on stock prices and bond ratings. We support results in Gande and Lewis (2009) showing that SCAS firms experience large negative stock price returns around the filing date. Peers' stock prices show signs of contagion with significant negative cumulative abnormal returns. These results suggest that corporate scandals do have a negative impact on their industry. We also show that bond ratings for SCAS companies drop significantly after the filing and the downgrading is stable up to three years after the event, suggesting that managerial misconduct has meaningful effects on all classes of securityholders.

These results allow us to shed light on the financing and security issuance behavior of firms whose frauds or other corporate wrongdoings are revealed. We conclude that independent of their intensity, corporate scandals do generate effects at both the firm and industry level by leading to a contraction in security offerings and a decrease in stock returns for all industry constituents.

The remainder of this paper is organized as follows. Section I summarizes previous work on corporate scandals and presents the hypotheses that we test in our study. Section II presents the data and summary statistics. Section III presents the results the empirical analysis of the financing pattern of firms engaged in corporate scandals. 
Section IV presents the results of the empirical analysis on security prices. Section V discusses the robustness tests performed, and Section VI concludes the paper.

\section{Motivation and Hypotheses}

\subsection{Corporate Scandals and Security Offerings}

Corporate scandals can be defined as widely publicized incidents involving allegations of managerial wrongdoing, disgrace, or moral outrage on the part of one or more members of a company. Typical instances of fraudulent behavior include misstatements of financial figures on current, past or future investments or operations, delay in disclosing or failure to disclose information, bribery, insider trading, and any other illegal activities that hurt the shareholders of the firm (Dyck, Morse and Zingales, 2010). A common feature of such misconducts is the biased, deferred or hindered revelation of information that would have had meaningful effects on managerial actions: first, it would have significantly reduced stock prices, making security offerings increasingly diluting and costly; secondly, it would have reasonably reduced (or canceled altogether) managerial independence in making capital structure-related decisions; thirdly, it would have heavily affected managers' payoffs, driving stock options out-of-the money, not triggering bonus payments or determining managers' firing. Managers, arguably, are aware of these effects and therefore have strong incentives to illegally preserve the information asymmetry and exploit it to increase the amount of funds that they collect in anticipation of potential capital and managerial constraints, trying to "make the most out of it while it lasts". Funds are then used in connection with the hidden information, to maintain or increase investments and R\&D spending, to pursue acquisitions, to rebalance (at a lower cost) the financial structure of the company or simply to enhance the liquidity stock in spirit similar to that in Ivashina and Scharfstein (2009). These managerial actions are likely to carry significant overinvestment costs for securityholders as shown by Jensen (1986). SCAS filing documents provide meaningful examples of these agency costs. In Cisco (2001), the plaintiff alleges that "[...] After completing more than 20 major acquisitions between 9/99 and 2/01, by issuing more than 400 million shares of Cisco stock, [...] on 2/6/01, Cisco announced extremely disappointing $2^{\text {nd }}$ Q F01 results"; similarly in Bay Networks (1997) it is alleged that: "[...] materially false or misleading statements enabled Bay Networks to Complete stock-for-stock acqui- 
sitions during the Class Period". Working capital financing is claimed by the plaintiff in SuperGen (2003): "[...] SuperGen sold millions of shares and notes [...] so as to provide it with ample monies to fund its operations. However, this all took place prior to revelations concerning the veracity of the Company's statements regarding Mitozytrex

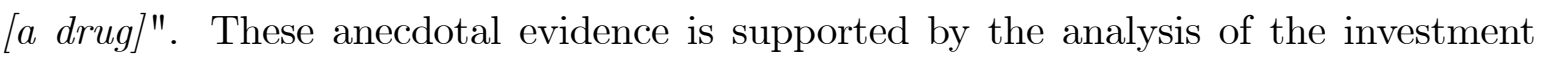
and dividend decisions of SCAS companies, reported in our Internet Appendix 1. We show that firms involved in a security class-action invest considerably more in $\mathrm{R} \& \mathrm{D}$, are twice more active in the M\&A market and acquisitions are up to three times more costly than that of their peers. Differently, and consistently with Harford, Mansi and Maxwell (2008), their dividend yields are considerably lower and often close to zero, suggesting the existence of severe agency costs. In this spirit we develop our first hypothesis:

Hypothesis 1: Ex-ante, firms engaged in wrongdoing leading to a corporate scandal have a greater amount of security offerings than the industry average

The Market Timing Hypothesis states that when making decisions about funding, managers take into account the current conditions of the debt and equity markets. Managers will choose the funding mechanism that looks pro-tempore optimal. However, if market conditions are unfavorable for both debt and equity issuance, fundraising might be deferred. Support for the market timing theory comes from the empirical evidence of managerial opportunism in setting financing policies (Graham and Harvey, 2001). Although this theory falls short in explaining many of the factors that have been traditionally considered in the studies of corporate capital structure, it is bolstered by strong empirical evidence that supports the existence of a behavioral component in managerial decisions. Baker and Wurgler (2002) build their capital structure predictions on the historical stock prices of firms, and further evidence confirms that stock prices indeed play an important role in explaining capital structure and capital structure changes (Welch, 2004). As for stock prices, the market timing hypothesis argues that firms tend to issue equity after the value of their stock has increased (Hovakimian, Opler and Titman, 2001) and that corporate leverage is best understood as the cumulative effect of past attempts to time the market (Baker and Wurgler, 2002). One important assumption underlying the market timing hypothesis is the possible existence of stock price misvaluation. If this occurs, managers of a firm that has overvalued (undervalued) stock price will opportunistically exploit this mispricing by issuing equity (debt). This latter fact was confirmed by Graham and Harvey (2001). In an interview survey of 392 U.S. and Canadian CFOs, $76 \%$ of the sample reported that the amount by which their 
stock was overvalued or undervalued was an "important" or "very important" factor in decisions about equity issuance.

Corporate scandals act as information revelation mechanisms for equity market participants. A scandal sheds new light on the actual managerial and accounting practices of the firm, revealing information that was previously unavailable to investors. Evidence show that in extreme cases ending in bankruptcy filing, investor reaction is strong and significant, with sharp declines in stock prices for the firms involved in the scandal (Lang and Stulz, 1992; Rao and Hamilton, 1996; Agrawal and Chadha, 2005). The stock price drop following such events can be interpreted as evidence of previous stock overvaluation either due to an accounting phenomenon (such as a misrepresentation of earnings) or because some information regarding the company's investments or risk exposure was not fully available to the market. Accordingly, we expect that:

Hypothesis 2: Ex-ante, firms engaged in wrongdoing leading to a corporate scandal made greater use of equity financing than the industry average.

If managers, due to information asymmetry that eventually leads to a scandal, time the market by issuing more equity when the stock is overvalued, then we can develop two ancillary predictions. First, once a scandal erupts, the abnormal security issuance pattern should revert towards the industry mean. Secondly, if their equity issuance is higher than that of their peers, leverage by construction should be lower. Accordingly, we define the following two hypotheses:

Hypothesis 3: After the corporate scandal is unveiled, the stock price of SCAS firms adjust to the fair price and firms' securities issuance aligns to the industry average.

Hypothesis 4: Ex-ante, firms engaged in wrongdoing leading to a corporate scandal have lower levels of leverage than the industry average.

Debt costs and volumes are highly sensitive to corporate information. Rating agencies are known to follow a rating stabilization objective that allows managers to plan the financial needs over a longer time horizon. Arguably, timely revelation of negative news about the company prospects can lead to a rating downgrade which immediately raises debt financing costs, increases financial rigidity and makes debt financing less attractive or nonviable. Managers have then an incentive to delay or prevent altogether the release of debt-price sensitive information. We therefore hypothesize : 
Hypothesis 5: The information revealed in a corporate scandal determines a longterm deterioration of the debt quality measured by its debt rating.

\subsection{Corporate Scandals and Contagion Effect}

Academic research on contagion effects at the corporate level has focused on the spillover of shocks occurring in one entity to other entities. Previous literature has explored the contagion effects on stock returns following bankruptcy (Lang and Stulz 1992), earning restatements (Gleason et al. 2008) and managerial forecast announcements (Ramnath, 2002). Similarly, Giesecke (2003) and Theocarides (2007) have explored contagion in the corporate bond market, showing that bond prices, yields and spreads react to firm-specific information. However, no previous study has investigated the existence of a contagion effect on capital structure decisions by companies. Because listed companies raise capital in the market, they are exposed to investor sentiments and market momentum and, possibly, to information concerning contiguous companies that investors may transfer to the entire industry. The financial crisis of 2008 has provided an illuminating example of this phenomenon, in which inherently sound companies have experienced the same dry-up in capital as weaker peers in their industry. Despite their managers' efforts, "the capital market window [was] just closed" for both high- and low-quality companies (Federal Reserve Board (2008)).

In this spirit, a SCAS filing is a signal that non-negligible mismanagement has occurred in one company. Investors may infer that this behavior can be common practice across the industry and therefore increase the competitors' capital constraints. A highly constrained financing environment leads to increased cost of external financing and ultimately to a contraction of the total security offerings of the industry. Furthermore, this effect should be amplified the by the degree of similarity among the firms' cash flows (Lang and Stulz, 1992). Thus, we generate the following hypothesis:

Hypothesis 6: The eruption of a corporate scandal will produce a contagion effect on the financing pattern of industry peers, generating a contraction in both debt and equity issuances.

A natural second step would be to evaluate whether corporate scandals also affect competitors' returns. Most studies of contagion effects have focused mainly on US bank failures (Kanas, 2005). These studies state that the failure of a large bank can undermine public confidence in the banking system as a whole, which may in turn threaten 
the stability of the financial system by causing runs on other banks (Diamond and Dybvig, 1983; Aharony and Swary, 1983; Swary, 1986). One seminal study on the topic of the contagion effect that departs from the banking industry investigates the effect of bankruptcy announcements on the equity value of a firm's competitors (Lang and Stulz, 1992). The authors find that on average, the market value of a weighted portfolio of the common stock of the bankrupt firm's competitors decreases by $1 \%$ at the time of the bankruptcy announcement and that this decline is statistically significant. Lang and Stulz (1992) test the existence of a contagion effect for non-financial firms at an intraindustry level; later Brewer and Jackson (2002) extended these results at the inter-industry level, working on a database of commercial banks and life insurance companies. Ferris et al. (1997) demonstrates that large firm bankruptcies generate a dominant contagion effect. Gande and Lewis (2009), documented statistically significant market price effects following a corporate scandal. Looking at security class actions, they use stock price returns, legal environment and the expected effects of a class action to develop a probabilistic model to predict the initiation of a SCAS. The corporate finance-related variables they use in their model are unexpected earnings and managerial compensation, but there is no metric addressing such capital structure phenomena. However, it is reasonable to expect that corporate scandal have a different impact on the stock prices of industry peers of a company involved in a SCAS conditional on previous capital structure decisions such as leverage and cash flow level. To test this intuition, we generate the following hypotheses:

Hypothesis 7: Ex-post, a corporate scandal will cause a negative contagion effect on industry peers' stock prices, and the contagion intensity is affected by the peers' capital structure characteristics.

\section{$2 \quad$ Data and summary statistics}

\subsection{Data}

Previous literature on corporate scandals has adopted earnings restatements, bankruptcy announcements and announcements of fraud in the press as measures of a scandal. In this paper, we depart from these approaches and proxy a corporate scandal

by the filing of a security class action suit in the United States, as emerging from the Stanford Securities Class Action Clearinghouse database. This definition of corporate 
scandal helps us generalize the results to a broader set of corporate events because it deals with less severe cases than financial default as only less than $10 \%$ of cases end in bankruptcy announcements. By adopting data at the Security Class Action level, we can test whether scandals do affect firms' and their peers' behavior conditional and unconditional on scandal intensity. Our database includes several types of corporate scandals, such as self-dealing frauds, disclosure failure, misrepresentation of accounting data, etc. One important concern, as highlighted by Dyck, Morse and Zingales (2010), is the possible inclusion of cases that may have simply been frivolous allegations. To deal with this potentially severe sample bias issue, we exclude actions filed before the passing of the Private Securities Litigation Reform Act of 1995 (PSLRA), which was designed with the goal, among others, of reducing courts' workload from frivolous claims. Additionally, we exclude dismissed cases, i.e. closed cases where the outcome has been a discharge from allegations.

The original Class Action Suits database has 2,479 cases from January 1996 to December 2006. We only keep cases filed between January 1996 and December 2005 to allow for the availability of at least two years of financial statement data after the suit filing. We then dropped highly specific SCASs classified as Analyst-related, IPO Allocation, Mutual Fund and Option Backdating (thus leaving only Classic SCAS cases). ${ }^{2}$ The rationale is that these cases are generally related to one isolated event (listings or managerial compensation) that is less likely to have an impact on a broader crosssection of security holders. Following Eckbo et al. (2008), we dropped private holdings, firms in the financial and utilities sectors (sic codes 6000-6999 and 4900-4999), and cases that did not have Compustat and CRSP information for the required period. The final sample reduces to 793 security class action suit cases. Fifty four percent (432) of the cases involve accounting allegations, and the remaining 46 percent (361) are classified as cases involving non-accounting allegations. At the time of the data collection, 16 percent (127) of the cases were still pending, while the remaining 84 percent (666) of the cases were already settled. We matched the firms from the SCAS database with

\footnotetext{
${ }^{2}$ The majority of the cases in the database are classified as Classic. "Classic" cases are cases involving 10(b) claims (misstatements or omissions) and/or other common securities law violations. Classic cases are also all cases that are not IPO Allocation, Analyst and Mutual Fund cases. "IPO Allocation cases" are cases filed from 2001 to 2002 alleging that underwriters engaged in undisclosed practices in connection with the distribution of certain IPO shares. "Analyst related cases" are cases filed from 2001 to 2004 alleging that the brokerage firm analysts falsely provided favorable coverage for certain issuers. These Analyst cases involve securities directly affected by allegedly false analyst research reports. "Mutual Fund cases" are cases filed from 2003 to 2004 alleging wrongful acts in the management of the funds.
} 
Compustat and CRSP using the firm's CUSIP. In the final sample of SCAS cases, we have 765 CUSIPs, meaning that several firms might have more than one security class action suit filing. Mean total assets in the filing year for these firms were $\$ 4,642.62$ million. The sample contains a total of 204 different 4-digit sic codes that we use to generate peer-groups comparisons. We classified each case according to the Fama and French (1997) industry classification to identify the dispersion of cases by industry,; on average, we have 21 different Fama and French industries in each filing year (see Table I) and a total of 41 industries.

\section{INSERT TABLE 1 HERE}

Finally, to ensure that security class action suits are not a proxy of bankruptcy, or more specifically of Chapter 11 filings, we matched our data with LoPucki's UCLA Bankruptcy Research Database. We manually merged information from the two databases and observed that on average, only less than $7 \%$ of the firms in our final sample filed for Chapter 11 in the period 2 years before or after the filing of the suit. This result allows us to argue that because SCASs are not a proxy for bankruptcy, capital structure changes are not a result of bankruptcy-driven corporate restructuring. Table II provides the distribution of cases included in our sample by event year, type of allegations and amount of companies that eventually filed for Chapter 11 in the two years before or after the filing of the security class action suit.

\section{INSERT TABLE 2 HERE}

To allow comparisons with the average financing behavior industry peers, for each event year we construct a measure given by the value-weighted portfolio of firms classified with the same 4-digit sic code and not involved in a SCAS.

\subsection{Variables definition}

We construct capital structure variables following Baker \& Wurgler (2002). Book equity is measured as total assets minus total liabilities and preferred stock plus deferred taxes and convertible debt. Market equity is measured as the number of common shares outstanding multiplied by the stock price. Book debt is measured as total assets minus book equity. Book leverage is measured as book debt divided by total assets. Market

leverage is measured as book debt divided by the sum of total assets minus book equity plus market equity. The amount of total (yearly) security offerings is measured as the 
sum of debt issuances and book equity issuances. Debt issuances are measured as the change in total assets minus the change in book equity divided by total assets. Book equity issuances are measured as the change in book equity minus the change in balance sheet retained earnings, divided by total assets ${ }^{3}$. Additionally, because debt and equity issuance are sometimes negative, indicating repurchases or voluntary cancellations of debt and equity, we constructed a dummy variable that is equal to one when either equity or debt issuances are smaller than zero, and zero otherwise.

\section{Corporate scandals and Capital Structure}

\subsection{Security offerings}

We conjectured that because fraud detection may affect the availability and cost of future financing, managers have incentives to take advantage of this information asymmetry to increase the amount of funds they raise. Similarly, we expected a firm engaged in a fraudulent behavior - such as a lack of disclosure of information and/or misstatement of accounts - to have a greater need of cash and liquidity, which would translate into a greater amount of capital raised. Based on this intuition, we compared the weighted average amount of security offerings by the sample of firms engaged in a SCAS with the average amount of offerings made by their peers (the value-weighted portfolio of the remaining firms with the same 4-digit sic code). The comparison was performed using data from the 6 -year window $\{-2,+3\}$ around the filing of the SCAS. Results reported in Table 3 offer support to our hypotheses.

\section{INSERT TABLE 3 HERE}

Ex-ante, firms engaged in a corporate scandal issue significantly more securities than their peers. However, this issuance pattern is abnormal and disappears after the SCAS filing. On average, two years before an event, firms engaged in a corporate scandal issue 5.35 times more securities than their peer sample. One year before the filing, abnormal security issuance starts decreasing but is still 2.52 times higher than that of industry peers. In the event year-i.e., when the SCAS is filed - abnormal issuance is twice that

\footnotetext{
${ }^{3}$ Debt and equity issues could also be measured using cash flow data. We used balance sheet data because there were more data available, and thus the amount of cases under analysis was larger.
} 
of the peer group. All differences are statistically significant at the $1 \%$ level on both one and two-tailed tests

Hypothesis 3 predicted that once the information gap with the market that allowed abnormal security issuance is eliminated, the issuance pattern should revert to the market mean. Results reported in table 3 confirm this intuition: in the three years following the SCAS filings, sued firms decrease their security offerings considerably, and their issuance pattern is not statistically different from that of their peers. In fact, there is mild (though insignificant) evidence that issuances are below the industry average. This result is not surprising and can be interpreted as evidence of an overshooting effect: the market reacts sharply to the SCAS, and prices drop below their "fair" value, reducing the chances for capital-raising.

\subsection{Financial mix: Equity and Debt offerings}

The previous analysis showed robust evidence of greater security issuance before a scandal erupts, which supports the idea that firms and managers exploited temporary overpricing due to undisclosed information. However, this information gap should affect equity more heavily than debt issuances. According to the Market Timing Hypothesis, firms with higher current stock prices (relative to their past stock prices, book values or earnings) are more likely to issue equity rather than debt and repurchase debt rather than equity (Hovakimian, Opler and Titman, 2001). On this basis, we hypothesized that the retained information allows firms to maintain overvalued stocks, leading to higher equity issuances. Accordingly, we expect these firms to show smaller evidence of differential issuance of public debt.

\section{INSERT TABLE 4 HERE}

The results reported in Table IV confirm our predictions. Ex-ante SCAS firms issue far more equity than their comparable weighted average portfolio of peers, and the difference is statistically significant for all years. Two years before the event, firms engaged in a corporate scandal issue 7.7 times more equity than does their peer sample. As with results observed for the security issuances test, this trend decreases over time, although its significance is consistently high at the $1 \%$ level. In particular, one year before the event $(t=-1)$ SCAS firms issued 4.26 times more than their peers; during the year when the security class action was filed, the abnormal equity issuance dropped to 
2.39 times the peer sample rate. As predicted, after the event, SCAS firms considerably reduce their equity issuances, which are never significantly different from the industry average.

Debt issuance evidence provides additional support to the hypotheses. Before the scandal is unveiled, SCAS firms make a remarkably smaller use of debt as opposed to equity. Cross-sectionally, debt offerings are aligned with those of the industry peers. with the exception of one year before the filing. However, financing decisions after the SCAS filing change sharply: equity issuances shrink and debt issuances turn negative and significant for the first two years of the event window. At $t=3$, debt issuance is still negative but not significant.

\subsection{Contagion effect on external financing decisions}

Firms in the peer sample show significantly different behavior, with both debt and equity offerings relatively stable in the two periods before and after the SCAS filing. Interestingly, issuance figures show strong evidence of discrete, one-time downward changes around the event date. Because figures are estimated over event windows distributed over a 10-year time horizon, it is not likely that this change is correlated with market conditions. Instead, we interpret this change as a possible consequence of a contagion effect on peers: when a SCAS is filed, investors may increase risk estimates indicating that other companies have engaged in similar practices, thus reducing stock prices and increasing debt required yields, which ultimately results in more costly capital and deferred or reduced capital-raising.

We further explore this evidence by modeling a trend variable $T$ which captures the evolution over time of external capital-raising The values of the trend variable range from $\{1,6\}$ and are linked to the event years so that $T$ is equal to one when the event year is $-2, T$ takes a value of two when the event year is -1 and so forth. We then explore trends in security offerings by performing the following cross-sectional randomeffects GLS regression:

$$
Y_{i t}=\alpha_{i}+\beta_{i} T+\varepsilon_{i T}
$$

where, $\mathrm{Y}_{i t}$ is the dependent variable capturing the aggregate $i^{\text {th }}$ industry equity, debt or total security offerings, $T$ is the trend variable, and $\varepsilon_{i t}$ is the error term of the regression. The regression results are robust to exogenous factors like market momentum, business cycles and sentiment because we are working with event years and not 
calendar years. Additional robustness tests are presented in Section 5.

Figure 1 and Table V show regression results for SCAS firms and their peers. Our results support the intuition in hypothesis 6: overall issuances decrease at an increasing rate over time for both subsamples. The trend coefficient for both subsamples is negative, statistically significant and, not surprisingly, larger for SCAS firms. The intercepts are large and positive, indicating positive net security issuance over time. Regression significance as captured by Wald statistic's $\chi^{2}$ is robustly significant at the $1 \%$ level.

\section{INSERT FIGURE 1 HERE}

\section{INSERT TABLE 5 HERE}

Breaking down the security issuance trend analysis by types of security, we find that debt and equity issuances decrease for both peers and SCAS firms. As reported in Figure 2 and Table V, the trend coefficient of the troubled firms is over 13 times larger than that of their peers.

\section{INSERT FIGURE 2 HERE}

Still, peers experience a negative, strongly significant coefficient, which indicates a contraction in capital-raising in public equity markets. The results for debt issuance are somewhat different. Not surprisingly, regression estimates for SCAS firms are not significant. This result can be explained recalling the evidence of debt issuance and book leverage of SCAS firms, which showed a strong decrease in debt issuance after the filing followed at $t=+2$ by a recovery. On the other hand, results for the peer group are strongly significant, with a negative coefficient for the trend variable, which indicates that a security class action suit against one competitor affects the debt capacity of the entire industry. As expected, results are stronger and more significant when interindustry similarity is higher as reported in Internet Appendix 2.

\subsection{Leverage}

The previous analyses show remarkable differences in the security issuance patterns of companies targeted by a SCAS and peers. However, these figures may not fully capture the complete set of financing decisions by companies. In fact, privately negotiated 
financing (e.g., bank loans) is by construction excluded from the data. This source of capital is largely used, in addition to publicly placed securities, to shape up companies' financial structures. In particular, following hypothesis 4 and previous results, we should expect market leverage not to be significantly different from that of the industry due to overpriced equity before the SCAS; we should also expect it to increase soon thereafter due to the strong adjustment in prices following the SCAS announcement. Similarly, book leverage should decrease before the filing as an effect of incremental equity increases and rise in the years that follow as evidence of greater use of nonpublic debt by the company due to too costly or closed market conditions.

We test these intuitions by analyzing the market and book leverage figures for companies sued by securityholders and the control peer group around the event date. The results reported in Table VI confirm these predictions.

\section{INSERT TABLE 6 HERE}

Firms engaged in SCAS show decreasing levels of book leverage before the event date, although differences with the peer groups are not significant except for the event year -2 . In contrast, book leverage differences increase significantly for all periods following the filing date. This result is fully generated by SCAS firms' changes because the peer group does not show any significant change in the average book leverage over the 5-year event window.

Market leverage figures are not largely different between the two groups before the filing date. However, we document a strongly significant increase in market leverage on the event date and for all the years that follow. Similarly to book leverage figures, market leverage figures for the peer group are constant over time, suggesting that differences are determined by drops in the market value of the equity of SCAS firms.

\subsection{Negative issuance}

Previous results have shown that both SCAS firms and their peers have a lower level of security issuance after a security class action filing. Interestingly, this phenomenon also generates cases of "negative issuance". Negative debt issuance can often be the simple repayment of outstanding debt without any rollover. In such a case, assuming that companies have a fairly stable short-term financial structure, the negative issuance pattern should be rather stable throughout the event window. However, if some extraordinary event occurs affecting the company's current and expected cash-flows, an 
abnormal negative issuance pattern becomes a signal of a debt restructuring process involving some degree of debt-cutting. Negative equity interpretation is less intuitive because book equity is a permanent liability on a company's balance sheet that is less easy to renegotiate. A possibility could be that the information revealed in a scandal triggers a profound restructuring that forces equityholders to write off some equity. However, it is extremely unlikely that this may happen without a formal procedure such as a Chapter 11 that occurs, in our sample, in less than $7 \%$ of the cases. Differently, it is possible that once the information is revealed, the firm may be prevented to invest -and overinvest - and be left with excess cash that is paid out to shareholders through buybacks as the stock price would most likely be not overpriced.

In table VII, we report figures for a simple discrete analysis of the number of firms for which debt and equity issuances figures were less than or equal to zero during the $\{-2,+3\}$ years surrounding the event.

\section{INSERT TABLE 7 HERE}

The results show that after the filing, SCAS firms retire and/or repurchase about $88 \%$ more equity and $74 \%$ more debt. In the SCAS subsample, negative debt issuance may be the result of debt repayment and cancellation due to restructuring taking place after the suit has been filed. Agrawal and Cooper (2007) show, in fact, that immediately after a scandal, most of the companies change their top management and initiate profound restructuring processes encompassing debt renegotiation as well. This same interpretation may apply to the equity figures because most of the restructuring plans imply large dilutions for existing shareholders, which result in negative changes in book equity and retained earnings.

Surprisingly, though, companies in the peer group also show an increasing amount of negative issuances. The differences are strong and significant across both samples and time. In line with our conjecture, we interpret this result as a contagion effect of the filing of a SCAS in the industry, which results in decreased opportunities for security offerings in the peer group around the event. 


\section{Corporate scandals and securities prices}

\subsection{Equity}

The previous results build on the argument that corporate scandals convey information about a firm's cash flows and accounting or management practices and that investors may consider them as signals of an industry-wide phenomenon than company-specific, isolated events. Such an inference should determine a negative effect on the stock prices of both SCAS firms and their peers, following the revelation of the scandal. Initial evidence of this effect and of the spillover to competitors has been provided by Gande and Lewis (2009). However, in their study, there is no evidence of any differential effect on stock prices conditional on capital structure and financial characteristics of the industry, which may arguably impact the magnitude of investors' response to scandals at the interindustry level. In this section, we begin by testing general effects on stock prices following a SCAS announcement and control for the settlement size, leverage and correlation of returns. We examine abnormal returns on a set of short-term windows (2 days, 3 days, 11 days, 13 days and 21 days around the event). We choose to restrict our study to short-term windows because working with a longer horizon could introduce noise into our results. The specific bracketings are constructed to capture quasi-instantaneous and anticipated or delayed stock price reactions to the filing announcement.

Following MacKinley (1997) and Khotari and Warner (2006), we estimate the normal performance using a standard market model with the following equation:

$$
R_{i t}=\alpha_{i}+\beta_{i} R_{m t}+\varepsilon_{i t}
$$

where $R_{i t}$ is the predicted normal rate of return of security $i$ at time $t, R_{m t}$ is the value-weighted return of the $\mathrm{S} \& \mathrm{P} 500$ index, $\alpha_{i}$ and $\beta_{i}$ are the estimated parameters, and $\varepsilon_{i t}$ is the error term of the regression. The distributions of stock returns are assumed to be jointly normal, independent and identically distributed over time: thus $E\left(\varepsilon_{i t}\right)=0$ and $\operatorname{var}\left(\varepsilon_{i t}\right)=\sigma_{\varepsilon_{i}}^{2}$. Equation (2) is estimated using trading days observations over the period $\{t-250, t-50\}$ preceding the filing of the class action suit at $t=0$. Using the estimated market model parameters, we compute daily abnormal returns for both sued firms and their peers' weighted average observations. The daily abnormal return of a security is computed by subtracting the predicted normal return from the actual return for each day in the event window. Letting $\widehat{A R}_{i t}$ be the abnormal returns for firm $i$ at time $t$, the sample abnormal return is: 


$$
\widehat{A R}_{i t}=R_{i t}-\left(\hat{\alpha}_{i}+\hat{\beta}_{i} R_{m t}\right)
$$

where $\widehat{A R}_{i \tau}$ is the abnormal rate of return of the security $i$ in the event window, $R_{i t}$ is the actual rate of return of the security $i$ in the event window, and $\left(\hat{\alpha}_{i}+\hat{\beta}_{i} R_{m \tau}\right)$ is the expected normal rate of return of the security $i$ in the event window calculated using the market model. The aggregation of abnormal returns is bi-dimensional: through time and across securities and follows this process: we first compute the average abnormal returns for all $i$ as:

$$
\overline{A R}_{t}=\frac{1}{N} \sum_{i=1}^{N} \widehat{A R}_{i t}
$$

For any security $i$, we then compute the cumulative abnormal return from $\tau_{1}$ to $\tau_{2}$ as the sum of the abnormal returns within that event window:

$$
\widehat{C A R}_{i}\left(t_{1}, t_{2}\right)=\sum_{t=t_{1}}^{t_{2}} \widehat{A R}_{i t}
$$

The average abnormal returns, across the $N$ SCAS companies, are aggregated over the event window as follows:

$$
\overline{C A R}\left(t_{1}, t_{2}\right)=\sum_{t=t_{1}}^{t_{2}} \overline{A R}_{t}
$$

Finally, we test whether the cumulative abnormal returns are statistically different from zero using:

$$
\theta_{1}=\frac{\overline{C A R}\left(t_{1}, t_{2}\right)}{\operatorname{var}\left(\overline{C A R}\left(t_{1}, t_{2}\right)\right)^{1 / 2}} \sim N(0 ; 1)
$$

This distributional result is asymptotic with respect to the $N$ number of securities and the length of the estimation window (201 trading days in this study).

We follow the same procedure for calculating $A R$ and $C A R$ for the 4-digit SIC code peer group of the sued company, excluding the latter from the estimations.

\subsubsection{Event study results}

Table VIII reports the event study results. 


\section{INSERT TABLE 8 HERE}

For SCAS firms, we observe significant, large negative returns for all estimation windows. In the 21-day window, the market price of sued firms dropped by $-19.84 \%$. Most of the observed CAR $(-17.64 \%)$ is generated in the $[-10,+1]$ window, with $-7.12 \%$ CAR observed in the three days around the filing date. The price adjustment process extends with significant daily abnormal returns up to three days after the filing and an additional - $2.2 \%$ significant CAR up to 10 days after the filing. Interestingly, our results are stronger in size and significance than those reported in Gande and Lewis (2009). We interpret this evidence as a result of the different sample adopted. In our sample, we have excluded financial companies and non-capital structure-relevant allegations such as IPO and option backdating-related filings. This different composition suggests that investors in industrial firms react to the information conveyed by the filing as a signal of greater risk exposure associated with all securities, and adjust their portfolios accordingly. This adjustment is confirmed by looking at the peer group. Stock price reactions are less strong but still significant, both around the event date and in a longer window, with CAR equal to $-0.21 \%,-0.56 \%$ an $-0.75 \%$ for, respectively, the $[-1,0],[-5,+5]$ and $[-10,+10]$ windows.

These price drops may seem somewhat surprising because companies' litigation damages are generally fully insured and the expected direct and indirect costs should be recovered. Gande and Lewis (2009) suggest that the downward adjustments are the result of shareholders' capitalization of future higher insurance premia, legal costs and loss of reputation. However, these additional costs are unlikely to be large enough to motivate these price adjustments. A different explanation is related with our previous evidence that companies involved in a security class action issue significantly more than their peers due to overvaluation. In this spirit, investors may therefore interpret the SCAS filing as a credible signal of previous overvaluation, thus sharply adjusting stock prices. Such a case carries a straightforward, testable implication: if SCAS reaction is a consequence of previous overvaluation, the magnitude of the reaction should be a function of the severity of the managerial misbehavior that supported inflated prices. Unfortunately, class actions are filed without any explicit monetary claim, making a direct test impossible. However, the filing claims and support documentation should allow investors to understand the likely outcome of the suit. In other words, investors may be able to measure the extent of managerial misbehavior by anticipating the potential monetary outcome. In such a case, CARs should be correlated with the realized 
SCAS settlements. We test this intuition by regressing the CARs of SCAS firms and peers over the monetary payments imposed by courts, as recorded by court documents extracted from a companion dataset of the SSCAC database. Our regressions take the following functional form:

$$
\overline{C A R}_{i}\left(t_{1}, t_{2}\right)=\alpha+\beta S_{i}+\varepsilon_{i}
$$

where $\overline{C A R}_{i}$ is the average Cumulative Abnormal Return over the event window $\left[t_{1}, t_{2}\right]$ for the $i$ SCAS firms or the control group and $S$ is the natural logarithm of the monetary settlement at the closing of the Security Class Action measured in millions. Table IX reports outcomes for these tests.

\section{INSERT TABLE 9 HERE}

The results support the intuition for all prediction windows with CAR size and significance increasing over the length of the event window. In particular, the larger the monetary settlement, the higher the ex-ante investors' reaction. This result suggests that investor can meaningfully discriminate between class actions and react accordingly. Peers results are unsurprisingly insignificant: the in-depth analysis of security class action filings is a highly firm-specific task, and.investors in other firms most likely react to the filing information per se without extensively screening the case. This generates a contagion effect that is less affected by expected settlement issues for the sued firms.

Similarly to the arguments put forth on financing policy decisions, stock price reactions following the announcement of a corporate scandal should be affected by the existing capital structure of the company and should generate larger effects on the industry peers' the higher the degree of similarity across firms, as conjectured in hypothesis 7. Table XII provides results for stock price reactions conditional on the degree of leverage of SCAS companies and their peers. Following Lang and Stulz (1992), we sorted firms according to a dummy variable equal to zero if the industry leverage mean was within the 1st and 50th percentile of the sample in the year of the filing (LOW leverage) and 1 otherwise.

\section{INSERT TABLE 10 HERE}


The results show that price reactions for SCAS firms are stronger for LOW-leverage industries than for HIGH-leverage ones. In particular, SCAS firms experience $-20.2 \%$ CAR over the $[-10,+10]$ window, while peers experience a significant $-0.71 \%$ CAR over the $[-5,+5]$ window. This result is only apparently counterintuitive: unlike in the capital structure analysis, in these tests we are looking at price reactions to events that may carry a signal of overvaluation. In such a case, an overvalued stock market price would result in lower market leverage. Therefore, when investors react to the SCAS announcement, the price adjustments generate a sharper reduction in price for companies that have high levels of equity and, therefore, low levels of leverage.

In Table XI, we control for cash flow similarity by introducing a dummy variable capturing the correlation of returns between the industry portfolio and the firms engaged in the corporate scandal in the years before the filing of the class action suit. This dummy takes a value of 1 if the correlation of returns falls within the top 50th percentile of the distribution (HIGH correlation) and zero otherwise (LOW correlation).

\section{INSERT TABLE 11 HERE}

The results validate the hypothesis highlighting that, for the HIGH correlation group, the contagion effect is approximately $25 \%$ stronger in both the $[-5,+5]$ and $[-10,+10]$ windows. Additionally, significant negative reactions are observed for the [$10,-2]$ and $[-10,+1]$ windows, supporting the idea that investors in the peer group are sensitive to the information incorporated in the SCAS filing if the sued firm and its competitors have similar operations and, therefore, similar risk exposure.

This intuition is confirmed by the insignificance of the results for the LOW correlation sub-sample in any window.

\subsection{Debt}

The previous results highlight that SCAS companies raise more equity than their peers by fraudulently exploiting information asymmetries with outside investors. The value of this information is captured by the sharp stock price reactions following the disclosure of managerial misconduct. However, our results show that SCAS companies also issued more debt in the period before the SCAS filing and that debtholders may be similarly affected by losses in value. If the information kept undisclosed at debt issuance is valuable, we should observe two effects upon its disclosure through the SCAS filing: 
first, a larger number of downgrades and a smaller number of upgrades in the period following the filing; and secondly, a consistent and stable drop in the average rating after the SCAS. We test this intuition by looking at the ratings and rating changes of the companies involved in a security class action, before and after the filing date. We collected S\&P ratings for SCAS companies in the 7-year period around the event date - i.e., $\{-3 ; 3\}$ - and calculated the average rating and changes in rating. S\&P ratings are expressed using a nominal 21-steps scale ranging from AAA (highest quality) to D (default). We ordinally converted each rating into a numeric format with 1 representing AAA and 21 representing D. A one-notch change is expressed by a one-integer decrease for downgrades and a one-integer increase for upgrades. We then used the numeric rating to calculate the average rating and rating changes over the event window. The results reported in Figure 3 robustly support the hypothesis that debtholders' value is affected by managerial misconduct.

\section{INSERT FIGURE 3 HERE}

Following the filing of a SCAS, the average rating drops by more than one notch, from an average rating of $\mathrm{BB}+$ to $\mathrm{BB}$, and the difference is significant at the $1 \%$ level. The frequency of downgrades increases significantly, and downgrades are much more severe than before the filing. Inversely, upgrades decrease significantly, and large upgrades disappear. Up to three years after the event, there is no evidence of a recovery in rating quality, indicating that the information disclosed in the SCAS filing was extremely valuable in the assessment of the long-term prospects of the issuing company.

\section{Robustness tests}

\subsection{Capital structure regressions}

Our results show robust evidence of abnormally higher security issuance by SCAS companies. We interpret this result as a rational choice by managers who do not fully disclose information on the company because truthful revelation may result in higher financing costs, affect managerial independence and reduce personal benefits. However, our evidence may be the result of a genuine higher need for capital by SCAS companies rather than the effect of a strategic use of asymmetric information. Following Rajan and Zingales (1995) and Baker and Wurgler (2002), we control the robustness of our 
conclusions for a set of additional determinants of capital structure. Previous results showed that SCAS firms issue largely in excess of their peers before the scandal but insignificantly different from peers after the class-action filing. The abnormal issuance pattern is downward sloping, i.e. reduces the closer the company is to the filing date, which we argued is a signal that managers can approximately anticipate the lawsuit filing. Since our objective is to test whether a SCAS triggers a significant change in the issuance decisions by SCAS companies and their peers conditional on the scandal revelation, we minimize the trend effect in our data by aggregating SCAS and peers observations into two groups: PRE and POST. In the PRE group we calculate average security issuances and control variables figures for four years before the filing, i.e. $\{-3,0\}$. In the POST group we calculate averages for the same variables for three years following the filing, $\{+1,+3\}$. This approach has the additional advantage of minimizing the problems associated with serial correlation in yearly security issuance data, as highlighted in Bertrand et al (2004). Our multivariate industry fixed-effects regression takes the following form:

$$
\begin{aligned}
Y_{i}= & \alpha+\beta_{1} G R O U P+\beta_{2} E V E N T+\beta_{3} G R O U P * E V E N T++\beta_{4} M T B_{i}+ \\
& +\beta_{5} \operatorname{LogSIZE} E_{i}+\beta_{6} E B I T D A / T A_{i}+\beta_{7} P P E / T A_{i}+\beta_{8} B E T A_{i}+F E+\varepsilon_{(}(9)
\end{aligned}
$$

where $Y_{i}$ is the dependent variable capturing total issuance by firm $i, G R O U P$ is the group operator taking value of 1 for SCAS companies an 0 otherwise, EVENT is the time operator taking value of one for pre-filing figures and 0 for post-filing observations, GROUP *EVENT is the interaction term, MTB is the Market-to-Book ratio, $\log S I Z E$ is the natural logarithm of the market capitalization of the company, $E B I T D A / T A$ is a profitability measure calculated by scaling operating profits by total assets, $P P E / T A$ is a fixed assets intensity measure calculate as total fixed assets scaled by total assets, $B E T A$ is the risk of the company measured by the $C R S P$ stock beta, and FE captures industry Fixed Effects based on the 41 Fama-French industries in our sample. Our previous results would be confirmed by a significant and positive parameter for the interaction term.

Results reported in Table XII support our previous analysis and provide additional intuitions. 


\section{INSERT TABLE 12 HERE}

Column 1-3 report results for the full sample of SCAS companies and peers. The interaction term is positive and strongly significant for all issuance measures. The EVENT parameter is small but positive which suggests the existence of a weak contagion effect as both peers and SCAS issue less after the event, consistent with results reported in Figure II and Table V. The GROUP parameter is negative and significant for debt issuance and for total security offerings, supporting arguments put forth in section 3.2. The control variables are significant in total security and equity issuance models only. Variables signs for all mdoels are aligned with those estimated in Rajan and Zingales (1995) and in Baker and Wurgler (2002) with the exception of the profitability variable for equity issuances that should be positive because raising equity determines a contraction in leverage. The signs of the estimated parameter for the Beta regressors, although insignificant, are aligned with standard literature prediction indicating that riskier firms issue comparably more equity than debt. The relatively low $R^{2}$ are not surprising because approximately $25 \%$ of our observations capture an issuance behavior by SCAS companies that we argue is abnormal and eventually disappears. The sign and significance of the interaction term support this interpretation but we provide further supporting evidence by running a set of regressions on the peers group only, including both PRE and POST data. We expect to obtain higher explanatory power of the regressions and parameters' significance. Results reported in Column 4-6 confirm our intuition: $R^{2}$ increase sharply and signs in the Debt and Equity models are largely significant and aligned with previous literature with the only exception given by the EBITDA/TA parameter that is positive and significant for Debt issuance while it is negative in Rajan and Zingales (1995) and in Baker and Wurgler (2002). Similarly, the sign is inverted in the Equity model although the estimated parameter is very small and insignificant. Finally, BETA parameters are aligned with previous regressions and turn significant, providing further support to the economic interpretation of our results.

\subsection{Reverse causality}

A possible concern in our analysis is the existence of a reverse-causality issue -i.e., the possibility that SCAS are initiated because investors observe abnormal security issuances, suggesting a "deep pocket" motivation for the initiation of the legal action. Intuitively, this should not be the case because the amendment to the Security Class 
Action regulation requires accurate and grounded hints of possible mismanagement and of the alleged effects on securities value. However, we cannot rule out the possibility of selection biases in the decision to initiate a class-action suit. In particular, we argue that if reverse-causality is in effect, we should observe differential evidence with respect to size and risk. Larger firms may be more likely to be sued because of the expectation of larger monetary settlements. On a different level, high-risk firms may show increased vulnerability to legal actions because of a behavioral bias on the part of investors in interpreting risk. More precisely, higher volatility in returns and valuations may be interpreted as a sign of managerial misconduct rather than as a normal effect of higher intrinsic risk, triggering a larger number of filings for high-risk companies. To control for these possible effects, we run a separate set of tests controlling whether larger companies were more likely to be sued than smaller companies as measured by the average and median size of companies in the SCAS sample as opposed to that of their peers. Similarly, we sort firms by risk level as measured by beta and control for the sample characteristics and the empirical evidence of capital raising and stock price reaction. For both tests, we find no evidence of a differential role for size and risk. ${ }^{4}$

Finally, we introduce an instrumental variable to conclusively test for reverse causality issues. We identify as the appropriate instrument the set of companies involved in a security class action, where the lawsuit outcome has been a dismissal. The rationale for this approach is that if investors are more likely to initiate a legal action against companies that issue more because they correlate abnormal issuance with a higher probability of managerial misconduct, then we should observe a similar security issuance pattern for SCAS and dismissed companies before the filing and no differences within the two groups or with the peer group after the filing. The empirical results do not support this hypothesis; we observe a significantly different pattern of security issuance between the SCAS group and the dismissed group.

\section{INSERT FIGURE 4 HERE}

In particular, the dismissed group shows a much more stable level of abnormal security issuance, clustered at about twice the level for the industry; secondly the dismissed group issuance before the filing is up to $60 \%$ lower than that of the SCAS sample; thirdly, and not surprisingly, the issuance pattern decreases around the filing date but

\footnotetext{
${ }^{4}$ The full set of tests is available through the Internet Appendix.
} 
reverts back to a level above the industry average and its own average after one year, indicating that security issuance above the peers' average level was motivated by actual financing needs related to development, operations and expansion; and lastly, while the SCAS group security issuance pattern does not differ meaningfully from that of their peer group after the filing, the dismissed group capital-raising pattern is significantly above the industry average. These results allow us to conclusively rule out the existence of reverse causality.

\subsection{Market sentiment, Chapter 11, size and type of allegation effects on capital structure and stock prices}

Several factors may be likely to affect the intensity of our results. In this section we perform a set of robustness tests by checking the capital structure and event study outcomes, conditional on the market sentiment in the year of the SCAS filing, the severity of the allegations as measured by whether the sued firm files for bankruptcy, the size of the companies (both the SCAS-targeted company and its peers), and the type of allegations.

Table XIII summarizes the tests' outcomes.

\section{INSERT TABLE 13 HERE.}

- Sentiment of the filing year

Arguably, market reactions should be stronger in negative market-sentiment years: if the market is already in a downturn, additional negative news will further increase the negative momentum of the stock and the expectations of the industry. In contrast, in positive market sentiment years, investors may be more lenient towards both sued companies and their peers, which will result in weaker reactions to both capital structure adjustments and prices. Using Baker and Wurgler's (2006) sentiment index, we run the set of analyses identifying the market sentiment of the SCAS filing year as high or low. All results are robust for both the capital structure and stock price hypotheses - with results, as expected, relatively stronger in low sentiment years.

- Chapter 11 filing

In the previous section, we have shown that investors seem to be able to determine the severity of SCAS cases and react accordingly. In this spirit, particularly severe cases 
ultimately ending in a bankruptcy filing should generate stronger effects on both SCAS firms and their peers. We control for this possible effect by matching our data with LoPucki's Bankruptcy Research Database at UCLA, generating a subsample given by sued companies that filed for Chapter 11 in the 2 years before and 2 years after the security class action suit filing. The results support the concept, with the exception of the book leverage pattern of SCAS firms, which does not decrease significantly before the filing.

- Size

In the previous paragraph we have controlled for a possible selection bias towards bigger firms. However, size may still be important in interpreting some cross-sectional variation in the results because information on large firms may provide stronger signals to the industry than those delivered by smaller firms. In a set of tests, we control for size using two different measures: first, we looked at the size of the SCAS firms as measured by total assets, dividing the sample into BIG and SMALL based on whether the SCAS firm total assets fall within the 51st and 100th percentile of the SCAS firms sample. We model the second measure in a similar fashion looking at the relative ranking of total assets with respect to the whole industry. The results are aligned with the expectations and offer some interesting additional evidence. In particular, the volume of security issuance for big SCAS firms according to the industry measure decreases much more sharply, falling below the peer average after the filing, which suggests that the market penalizes big firms relatively more than small ones. This effect seems to be known to small firms, which issue issue more than the aggregate SCAS' firm samples.

- Type of allegations

Finally, we control for the security issuance pattern conditional on the type of allegation of the security class action suit. We have previously shown that accounting allegations generate stronger price reactions around the filing date. However, while investors may be immediately less sensitive to the information conveyed by a nonaccounting-related filing, they may process this additional information in the long term, which will affect the future financing patterns of sued companies and, through contagion, those of their peers as well. The results fully support this intuition, showing no meaningful differences in the outcomes of the capital structure tests for accounting- and non-accounting-related security class actions. 


\section{Conclusions}

Corporate scandals have attracted considerable attention because their large, negative effects on shareholder value. In this paper, we argue that corporate managers are aware of these effects and try to anticipate higher future costs in capital-raising by abnormally issuing more securities before a corporate scandal is unveiled. By measuring corporate scandals as the filing of security class action suits, we additionally argue that investors may interpret such an event as a signal of deterioration in the industry as a whole, thus generating significant negative contagion effects on the capital-raising opportunities and share price levels of a firm's competitors. Our results provide robust evidence that firms involved in a corporate scandal issue significantly more securities before the filing; also, in particular, they raise more equity than their industry peers. After a scandal surfaces, both sued firms and their peers face constraints in further capitalraising, which results in decreasing issuance and lower bond ratings. Additionally, we document significant stock and bond price effects around the SCAS filing date that affect all industry constituents. Both capital structure and the share price reactions increase based on the similarity of the operating and financial characteristics of sued firms and their industry peers. Our results suggest that managers "time" the market by exploiting transient overvaluation in anticipation of future more costly or reduced fund-raising opportunities. However, markets evaluate information revealed in a corporate scandal as a possibly widespread phenomenon, generating negative fall-out that also affects peers' financing opportunities. These results have important implications because they suggest that financial structures are the result of firm-level choices and market conditions, as suggested by Baker and Wurgler (2006), but also of industry-level information and behavioral components of managerial decisions. 


\section{References}

Agrawal, A, Chadha S., 2005, Corporate governance and accounting scandals, Journal of Law and Economics 48, 371-406.

Agrawal, A, Cooper T., 2007, Corporate governance consequences of accounting scandals: Evidence from top management, CFO and Auditor Turnover, 2nd Annual Conference on Empirical Legal Studies Paper. AFA 2009 San Francisco Meetings Paper.

Baker, M, WurglerJ., 2002, Market Timing and Capital Structure, The Journal of Finance 57, 1-32.

Baker, M, WurglerJ., 2006, Investor sentiment and the cross-section of stock returns, The Journal of Finance 61, 1645-1680.

Bay Networks (1997) Case docket number: 97-CV-728, Court: N.D. California, Filing date 02/28/1997.

Bertrand M. Duflo E. and Mullainhatan S. 2004, How Much Should We Trust Differences-in-Differences Estimates?, The Quarterly Journal of Economics, v. 119, n. 1, p. 249-275.

Brewer E, Jackson W.E., 2002, Inter-Industry Contagion and the Competitive Effects of Financial Distress Announcements: Evidence from Commercial Banks and Life Insurance Companies, Federal Reserve Bank of Chicago, Working paper No. 2002-23.

Cisco (2001), Case docket number: 01-CV-20418, Court: N.D. California, Filing date $4 / 20 / 2001$.

De Bondt W. F. M., Thaler R., 1985, Does the Stock Market Overreact?, The Journal of Finance 40, 3, 793-805.

De Bondt W. F. M., Thaler R., 1990, Do Security Analysts Overreact?, The American Economic Review, 80, 2, 52-57.

Dyck, I. J. A., Morse, A., Zingales L., 2010, Who blows the whistle on corporate fraud?, Journal of Finance, fortchoming..

Eckbo E. Masulis, R., and Norli, O., 2008, Security Offerings, in Handbook of Empirical Corporate Finance, E. Eckbo Editor, North Holland, Chapter 6.

Fama, E. F., French K. R., 1997, Industry Costs of Equity,Journal of Financial Economics, 43, 153-193.

Fama, E. F., French K. R., 2002, Testing Trade-Off and Pecking Order predictions about Dividends and Debt, Review of Financial Studies 15, 1-33.

Federal reserve Board (2008), The October 2008 Senior Loan Officer Opinion Survey on Bank Lending Practices, October, Board of Governors of the Federal Reserve System, 
Washington, USA, http://www.federalreserve.gov/boarddocs/surveys.

Ferris, S. P., Jayaraman, N., Makhija, A., 1997, The response of competitors to announcements of bankruptcy: An empirical examination of contagion and competitive effects, Journal of Corporate Finance 3, 367-395.

Francis, J., Philbrick, D. and Schipper, K., Shareholder Litigation and Corporate Disclosures, Journal of Accounting Research, Vol. 32, No. 2, Autumn 1994, pp. 137164.

Gande, A. and Lewis, C. M.,Shareholder Initiated Class Action Lawsuits: Shareholder Wealth Effects and Industry Spillovers. Journal of Financial and Quantitative Analysis (JFQA), Forthcoming.

Gieseke K., Correlated default with incomplete information, Journal of Banking \& Finance Volume 28, Issue 7, July 2004.

Gleason, C., W.B. Johnson and N.T. Jenkins. 2008. Financial statement credibility: the contagion effects of accounting restatements. The Accounting Review 81 (83-110).

Graham, J.R., 2000, How big are tax benefits of Debt?, Journal of Finance 55, 1901-1941.

Graham, J. R., Harvey C., 2001, How do CFOs make capital budgeting and capital structure decisions?, Journal of Financial Economics 60, 187-243.

Harford J., Mansi S., and Maxwell W., 2008, Corporate governance and firm cash holdings in the US, Journal of Financial Economics, 87, 3.

Hovakimian, A., Opler, T., Titman S., 2001, The Debt-Equity choice, The Journal of Financial and Quantitative Analysis 36, 1-24.

Hubbard, R. G., 1998. Capital-market imperfections and investment, Journal of Economic Literature 36, 193-225.

Ivashina, V. and Scharfstein, D. S., 2009, Bank Lending During the Financial Crisis of 2008. Available at SSRN: http://ssrn.com/abstract=1297337

Jensen M. C., The Agency Costs of Free Cash Flow: Corporate Finance and Takeovers, American Economic Review, Vol. 76, No. 2

John K. and Kalay , 2982, Costly Contracting and Optimal Pay-Out Constraints, The Journal of Finance, 1982, Vol. 37, No. 2.

Kanas, A., 2005, Pure Contagion Effects in International Banking: The case of BCCI's Failure. Journal of Applied Economics 8, 101-123.

Khotari, S.P., Warner J. P., 2006, Econometrics of event studies, in B. Espen Eckbo, ed: Handbook of Corporate Finance: Empirical Corporate Finance, Handbooks in Finance Series (Elsevier/North-Holland). 
Lang, L., Stulz, R., 1992, Contagion and competitive intra-industry effects of bankruptcy announcements: An empirical analysis, Journal of Financial Economics 32, 4560.

MacKinlay, A. C., 1997, Event studies in economics and finance, Journal of Economic Literature, 35, 13-39.

Markham, J., 2006, A Financial History of Modern U.S. Corporate Scandals: from Enron to Reform, (M.E. Sharpe.London, England)

Mikkelson, W. H., Partch M. M., 1985, Stock price effects and costs of secondary distributions, Journal of Financial Economics 14, 165-194.

Miller, M. H., 1977, Debt and taxes, Journal of Finance 32, 261-275.

Miller, M. H. and Rock, K., 1985, Dividend Policy under Asymmetric Information, Journal of Finance, vol. 40(4),1031-51.

Myers, S. C., 1984, The Capital Structure Puzzle, The Journal of Finance 39, 575592.

Myers S. C., 2001, Capital Structure, The Journal of Economic Perspectives 15, 81-102.

Palmrose, Z., Richardson, V.J., Scholz S., 2004, Determinants of market reactions to restatement announcements, Journal of Accounting and Economics 37, 59-89.

Rajan R., Zingales L., 1995, What do we know about capital structure? Some evidence from international data, Journal of Finance, 50, 1421-1460.

Rao, S., Brooke Hamilton J., 1996, The Effect of Published Reports of Unethical Conduct on Stock Prices, Journal of Business Ethics 15, 1321-1330.

Ramnath, S. 2002. Investor and analyst reactions to earnings announcements of related firms: an empirical analysis. Journal of Accounting Research 40(5): 1351-1376.

Romano, R. 1991, The Shareholder Suit: Litigation Without Foundation?, Journal of Law, Economics, \& Organization, 55-87

SuperGen, 2003, Case docket number: 03-CV-1576, Court: N.D. California, Filing date $04 / 14 / 2003$.

Theocharides, G., 2007, Contagion: Evidence from the Bond Market. Available at SSRN: http://ssrn.com/abstract $=811548$

Welch, I., 2004, Capital Structure and Stock returns, Journal of Political Economy $112,106-131$ 
Table I

Yearly distribution of events and

Fama \& French industries

This table reports the distribution of security class action suit cases by filing year, from January 1996 to December 2006. Fama \& French industries were assigned using 4-digit sic codes and the classification provided in Fama and French (1997).

\begin{tabular}{clc}
\hline Filing year (SCAS) & N & Fama French industries \\
\hline 1996 & 47 & 19 \\
1997 & 66 & 22 \\
1998 & 88 & 24 \\
1999 & 75 & 22 \\
2000 & 87 & 21 \\
2001 & 81 & 20 \\
2002 & 90 & 25 \\
2003 & 63 & 21 \\
2004 & 82 & 21 \\
2005 & 67 & 24 \\
2006 & 47 & 18 \\
& & \\
Total & 793 & 41 \\
\hline
\end{tabular}

Table II

Amount of cases studies by event year, type of allegation and chapter 11 filing

This table reports the distribution of security class action suit cases by event year. The event year $(t=0)$ is defined as the year in which the security class action suit was filed against the firm. The percentages of cases according to the type of allegation (accounting and non-accounting), and to the filing of chapter 11 (2 years after or before the filing) are also presented.

\begin{tabular}{cccccc}
\hline Year (event) & $\mathrm{N}$ & $\begin{array}{c}\text { Accounting } \\
\text { allegations }\end{array}$ & $\begin{array}{c}\text { Non-accounting } \\
\text { allegations }\end{array}$ & $\begin{array}{c}\text { Filed for } \\
\text { Chapter 11 in } \\
\mathrm{t}=[-2,2]\end{array}$ & $\begin{array}{c}\text { Didn't file for } \\
\text { Chapter 11 in } \\
\mathrm{t}=[-2,2]\end{array}$ \\
\hline $\mathrm{t}=-3$ & 735 & $55.50 \%$ & $44.50 \%$ & $8.50 \%$ & $91.50 \%$ \\
$\mathrm{t}=-2$ & 754 & $55.00 \%$ & $45.00 \%$ & $8.80 \%$ & $91.20 \%$ \\
$\mathrm{t}=-1$ & 717 & $54.30 \%$ & $45.70 \%$ & $7.60 \%$ & $92.40 \%$ \\
$\mathrm{t}=0$ & 627 & $53.40 \%$ & $46.60 \%$ & $5.40 \%$ & $94.60 \%$ \\
$\mathrm{t}=1$ & 551 & $53.40 \%$ & $46.60 \%$ & $4.40 \%$ & $95.60 \%$ \\
$\mathrm{t}=2$ & 458 & $54.80 \%$ & $45.20 \%$ & $4.20 \%$ & $95.80 \%$ \\
$\mathrm{t}=3$ & 366 & $54.80 \%$ & $45.20 \%$ & $4.00 \%$ & $96.00 \%$ \\
\hline
\end{tabular}


Table III

\section{Mean security offerings by event year}

This table reports the total mean security offerings of firms engaged in a corporate scandal (proxied by the filing of a security class action suit), and that of a value-weighted portfolio of the remaining firms with the same 4-digit sic code (by event year). The event year $(t=0)$ is defined as the year in which the security class action suit was filed against the firm. The amount of total -yearly- security offerings is measured as the sum of debt issuances and book equity issuances. Debt issuances are measured as the change in total assets minus change in book equity divided by total assets. Book equity issuances are measured as the change in book equity minus the change in balance sheet retained earnings, divided by total assets. The last two columns of the table present the results of the one and two-tailed mean-difference tests.

\begin{tabular}{|c|c|c|c|c|c|c|}
\hline $\mathrm{t}$ & Variable & Obs & Mean & Mean(diff) & $\operatorname{Pr}(|\mathrm{T}|>|\mathrm{t}|)^{(1)}$ & $\operatorname{Pr}(\mathrm{T}>\mathrm{t})^{(2)}$ \\
\hline-2 & Security offerings SCAS & 629 & 0.576 & & & \\
\hline-2 & Security offerings PEERS & 629 & 0.108 & 0.469 & $0.000(* * *)$ & $0.000(* * *)$ \\
\hline-1 & Security offerings SCAS & 638 & 0.390 & & & \\
\hline-1 & Security offerings PEERS & 638 & 0.111 & 0.279 & $0.000(* * *)$ & $0.000(* * *)$ \\
\hline 0 & Security offerings SCAS & 553 & 0.184 & & & \\
\hline 0 & Security offerings PEERS & 553 & 0.092 & 0.092 & $0.000(* * *)$ & $0.000(* * *)$ \\
\hline 1 & Security offerings SCAS & 483 & 0.042 & & & \\
\hline 1 & Security offerings PEERS & 483 & 0.072 & -0.030 & 0.409 & 0.796 \\
\hline 2 & Security offerings SCAS & 403 & 0.064 & & & \\
\hline 2 & Security offerings PEERS & 403 & 0.069 & -0.004 & 0.884 & 0.558 \\
\hline 3 & Security offerings SCAS & 322 & 0.074 & & & \\
\hline 3 & Security offerings PEERS & 322 & 0.067 & 0.007 & 0.928 & 0.464 \\
\hline
\end{tabular}

\footnotetext{
${ }^{(1)}$ Ha: mean $($ diff $) \neq 0$

${ }^{(2)} \mathrm{Ha}$ : mean (diff) $>0$
} 


\section{Table IV}

Mean debt and equity issuances by event year

This table reports mean equity and debt issuances of firms engaged in a corporate scandal (proxied by the filing of a security class action suit), and a value-weighted portfolio of the remaining firms with the same 4-digit sic code (by event year). The event year ( $t=0$ ) is defined as the year in which the security class action suit was filed against the firm. Debt issuances are measured as the change in total assets minus change in book equity divided by total assets. Book equity issuances are measured as the change in book equity minus the change in balance sheet retained earnings, divided by total assets. The last three columns of the table present the results of the one and two-tailed mean-difference tests.

\section{EQUITY}

\begin{tabular}{|c|c|c|c|c|c|c|c|}
\hline $\mathrm{t}$ & Variable & Obs & Mean & Mean (diff) & $\operatorname{Pr}(|\mathrm{T}|>|\mathrm{t}|)^{(1)}$ & $\operatorname{Pr}(\mathrm{T}>\mathrm{t})^{(2)}$ & $\operatorname{Pr}(\mathrm{T}<\mathrm{t})^{(3)}$ \\
\hline-2 & Equity issuances SCAS & 629 & 0.538 & & & & \\
\hline-2 & Equity issuances PEERS & 629 & 0.070 & 0.468 & $0.018(* *)$ & $0.009(* * *)$ & 0.991 \\
\hline-1 & Equity issuances SCAS & 638 & 0.309 & & & & \\
\hline-1 & Equity issuances PEERS & 638 & 0.072 & 0.236 & $0.000(* * *)$ & $0.000(* * *)$ & 1.000 \\
\hline 0 & Equity issuances SCAS & 553 & 0.148 & & & & \\
\hline 0 & Equity issuances PEERS & 553 & 0.062 & 0.086 & $0.000(* * *)$ & $0.000(* * *)$ & 1.000 \\
\hline 1 & Equity issuances SCAS & 483 & 0.074 & & & & \\
\hline 1 & Equity issuances PEERS & 483 & 0.045 & 0.029 & 0.256 & 0.128 & 0.872 \\
\hline 2 & Equity issuances SCAS & 403 & 0.089 & & & & \\
\hline 2 & Equity issuances PEERS & 403 & 0.046 & 0.043 & $0.089\left(^{*}\right)$ & $0.044(*)$ & 0.956 \\
\hline 3 & Equity issuances SCAS & 322 & 0.082 & & & & \\
\hline 3 & Equity issuances PEERS & 322 & 0.043 & 0.039 & $0.091(*)$ & $0.046(*)$ & 0.955 \\
\hline \multicolumn{8}{|c|}{ DEBT } \\
\hline $\mathrm{t}$ & Variable & Obs & Mean & Mean (diff) & $\operatorname{Pr}(|\mathrm{T}|>|\mathrm{t}|)^{(1)}$ & $\operatorname{Pr}(\mathrm{T}>\mathrm{t})^{(2)}$ & $\operatorname{Pr}(\mathrm{T}<\mathrm{t})^{(3)}$ \\
\hline-2 & Debt issuances SCAS & 632 & 0.038 & & & & \\
\hline-2 & Debt issuances PEERS & 632 & 0.040 & -0.002 & 0.990 & 0.505 & 0.495 \\
\hline-1 & Debt issuances SCAS & 640 & 0.081 & & & & \\
\hline-1 & Debt issuances PEERS & 640 & 0.039 & 0.042 & $0.008(* * *)$ & $0.004(* * *)$ & 0.996 \\
\hline 0 & Debt issuances SCAS & 555 & 0.036 & & & & \\
\hline 0 & Debt issuances PEERS & 555 & 0.032 & 0.004 & 0.766 & 0.383 & 0.617 \\
\hline 1 & Debt issuances SCAS & 485 & -0.033 & & & & \\
\hline 1 & Debt issuances PEERS & 485 & 0.029 & -0.062 & $0.003(* * *)$ & 0.999 & $0.001(* * *)$ \\
\hline 2 & Debt issuances SCAS & 406 & -0.025 & & & & \\
\hline 2 & Debt issuances PEERS & 406 & 0.024 & -0.049 & $0.069 \quad(*)$ & 0.966 & $0.034(* *)$ \\
\hline 3 & Debt issuances SCAS & 325 & -0.011 & & & & \\
\hline 3 & Debt issuances PEERS & 325 & 0.025 & -0.035 & 0.568 & 0.716 & 0.284 \\
\hline
\end{tabular}

\footnotetext{
${ }^{(1)} \mathrm{Ha}$ : mean (diff) $\neq 0$

${ }^{(2)} \mathrm{Ha}$ : mean (diff) $>0$

${ }^{(3)} \mathrm{Ha}$ : mean (diff) $<0$
} 


\section{Table V}

\section{Security offering trend analysis}

This table reports the results of the regression: $\mathrm{Y}_{\mathrm{iT}}=\alpha_{\mathrm{i}}+\beta_{\mathrm{i}} \mathrm{T}+\varepsilon_{\mathrm{it}}$; where, $\mathrm{Y}_{\mathrm{iT}}$ are either equity, debt or total security issuances, $\mathrm{T}$ is a trend variable that ranges from $\{1,6\}$ representing event years $\{-2,3\}$, and $\varepsilon_{\mathrm{iT}}$ is the error term of the regression. The amount of total -yearly- security offerings is measured as the sum of debt issuances and book equity issuances. Debt issuances are measured as the change in total assets minus change in book equity divided by total assets. Book equity issuances are measured as the change in book equity minus the change in balance sheet retained earnings, divided by total assets.

\section{SCAS}

\begin{tabular}{|c|c|c|c|}
\hline Dependent variable & $\begin{array}{c}\text { Total security } \\
\text { offerings }\end{array}$ & Equity issuances & Debt issuances \\
\hline Intercept & $0.586(* * *)$ & $0.510(* * *)$ & 0.082 \\
\hline $\mathrm{P}>|\mathrm{z}|$ & 0.000 & 0.000 & 0.313 \\
\hline Trend coeff. & $-0.093(* * *)$ & $-0.078(* * *)$ & -0.019 \\
\hline $\mathrm{P}>|\mathrm{z}|$ & 0.000 & 0.001 & 0.392 \\
\hline $\mathrm{N}$ & 721 & 721 & 724 \\
\hline Wald chi-square & $32.05(* * *)$ & $10.67(* * *)$ & 0.73 \\
\hline $\mathrm{P}>$ chi-square & 0.000 & -0.001 & -0.392 \\
\hline \multicolumn{4}{|c|}{ PEERS } \\
\hline Dependent variable & $\begin{array}{c}\text { Total security } \\
\text { offerings }\end{array}$ & Equity issuances & Debt issuances \\
\hline Intercept & $0.120(* * *)$ & $0.078(* * *)$ & $0.045(* * *)$ \\
\hline $\mathrm{P}>|\mathrm{z}|$ & 0.000 & 0.000 & 0.000 \\
\hline Trend coeff. & $-0.009(* * *)$ & $-0.006(* * *)$ & $-0.004(* * *)$ \\
\hline $\mathrm{P}>|\mathrm{z}|$ & 0.000 & 0.000 & 0.000 \\
\hline $\mathrm{N}$ & 782 & 782 & 782 \\
\hline Wald chi-square & $57.18(* * *)$ & $47.75(* * *)$ & $21.96(* * *)$ \\
\hline $\mathrm{P}>$ chi-square & 0.000 & 0.000 & 0.000 \\
\hline
\end{tabular}




\section{Table VI}

\section{Market and book leverage by event year}

This table reports the mean market and book leverage of firms engaged in a corporate scandal (proxied by the filing of a security class action suit), and for a the value-weighted portfolio of firms with the same 4-digit sic code by event year, excluding the SCAS firm. The event year $(t=0)$ is defined as the year in which the security class action suit was filed against the firm. Market leverage is measured as book debt divided by the sum of total assets minus book equity plus market equity. Book leverage is measured as book debt divided by total assets. The last two columns of the table present the results of the one and two-tailed mean-difference tests.

\section{MARKET LEVERAGE}

\begin{tabular}{|c|c|c|c|c|c|c|}
\hline $\mathrm{t}$ & Variable & Obs & Mean & Mean(diff) & $\operatorname{Pr}(|\mathrm{T}|>|\mathrm{t}|)^{(1)}$ & $\operatorname{Pr}(\mathrm{T}>\mathrm{t})^{(2)}$ \\
\hline-2 & Market leverage SCAS & 607 & 0.236 & & & \\
\hline-2 & Market leverage PEERS & 607 & 0.233 & 0.003 & 0.719 & 0.359 \\
\hline-1 & Market leverage SCAS & 633 & 0.252 & & & \\
\hline-1 & Market leverage PEERS & 633 & 0.234 & 0.018 & $0.050(* *)$ & $0.025(* *)$ \\
\hline 0 & Market leverage SCAS & 570 & 0.372 & & & \\
\hline 0 & Market leverage PEERS & 570 & 0.237 & 0.135 & $0.000(* * *)$ & $0.000(* * *)$ \\
\hline 1 & Market leverage SCAS & 498 & 0.381 & & & \\
\hline 1 & Market leverage PEERS & 498 & 0.239 & 0.142 & $0.000(* * *)$ & $0.000(* * *)$ \\
\hline 2 & Market leverage SCAS & 417 & 0.360 & & & \\
\hline 2 & Market leverage PEERS & 417 & 0.231 & 0.129 & $0.000(* * *)$ & $0.000(* * *)$ \\
\hline 3 & Market leverage SCAS & 327 & 0.365 & & & \\
\hline 3 & Market leverage PEERS & 327 & 0.230 & 0.135 & $0.000(* * *)$ & $0.000(* * *)$ \\
\hline \multicolumn{7}{|c|}{ BOOK LEVERAGE } \\
\hline $\mathrm{t}$ & Variable & Obs & Mean & Mean(diff) & $\operatorname{Pr}(|T|>|t|)^{(1)}$ & $\operatorname{Pr}(\mathrm{T}>\mathrm{t})^{(2)}$ \\
\hline-2 & Book leverage SCAS & 706 & 0.653 & & & \\
\hline-2 & Book leverage PEERS & 706 & 0.430 & 0.223 & $0.027(* *)$ & $0.013(* *)$ \\
\hline-1 & Book leverage SCAS & 660 & 0.483 & & & \\
\hline-1 & Book leverage PEERS & 660 & 0.423 & 0.060 & 0.106 & $0.053(*)$ \\
\hline 0 & Book leverage SCAS & 572 & 0.526 & & & \\
\hline 0 & Book leverage PEERS & 572 & 0.425 & 0.101 & $0.000(* * *)$ & $0.000(* * *)$ \\
\hline 1 & Book leverage SCAS & 501 & 0.626 & & & \\
\hline 1 & Book leverage PEERS & 501 & 0.435 & 0.191 & $0.007(* * *)$ & $0.003(* * *)$ \\
\hline 2 & Book leverage SCAS & 420 & 0.581 & & & \\
\hline 2 & Book leverage PEERS & 420 & 0.421 & 0.161 & $0.000(* * *)$ & $0.000(* * *)$ \\
\hline 3 & Book leverage SCAS & 330 & 0.755 & & & \\
\hline 3 & Book leverage PEERS & 330 & 0.419 & 0.336 & $0.037(* *)$ & $0.019(* *)$ \\
\hline
\end{tabular}

${ }^{(1)} \mathrm{Ha}: \operatorname{mean}($ diff $) \neq 0$

${ }^{(2)} \mathrm{Ha}$ : mean (diff) $>0$ 


\section{Table VII}

Negative Issuance

This table reports the results of a discrete analysis of negative debt and equity issuances in the different event years. For each event year we calculated the number of case where debt/equity issuances were less or equal than zero. Percentage are calculated on the total number of observations.

Equity issuances

\begin{tabular}{|c|c|c|c|c|c|c|}
\hline \multirow[b]{2}{*}{$\mathrm{t}$} & \multicolumn{3}{|c|}{ SCAS } & \multicolumn{3}{|c|}{ PEERS } \\
\hline & Obs & Eq_iss $<=0$ & $\mathrm{Eq}$ _iss $<=0(\%)$ & Obs & $\mathrm{Eq}$ _iss $<=0$ & $\%$ Eq_iss $<=0$ \\
\hline-2 & 629 & 90 & $14.31 \%$ & 754 & 91 & $12.10 \%$ \\
\hline-1 & 638 & 95 & $14.89 \%$ & 717 & 103 & $14.40 \%$ \\
\hline 0 & 553 & 145 & $26.22 \%$ & 627 & 99 & $15.80 \%$ \\
\hline 1 & 483 & 135 & $27.95 \%$ & 551 & 108 & $19.60 \%$ \\
\hline 2 & 403 & 105 & $26.05 \%$ & 458 & 97 & $21.20 \%$ \\
\hline 3 & 322 & 96 & $29.81 \%$ & 366 & 73 & $19.90 \%$ \\
\hline
\end{tabular}

Debt issuances

\begin{tabular}{|c|c|c|c|c|c|c|}
\hline \multirow[b]{2}{*}{$\mathrm{t}$} & \multicolumn{3}{|c|}{ SCAS } & \multicolumn{3}{|c|}{ PEERS } \\
\hline & Obs & Debt_iss $<=0$ & $\%$ Debt_iss $<=0$ & Obs & Debt_iss $<=0$ & $\%$ Debt_iss $<=0$ \\
\hline-2 & 632 & 175 & $27.69 \%$ & 754 & 154 & $20.40 \%$ \\
\hline-1 & 640 & 174 & $27.19 \%$ & 717 & 135 & $18.80 \%$ \\
\hline 0 & 555 & 211 & $38.02 \%$ & 627 & 153 & $24.40 \%$ \\
\hline 1 & 485 & 244 & $50.31 \%$ & 551 & 128 & $23.20 \%$ \\
\hline 2 & 406 & 217 & $53.45 \%$ & 458 & 109 & $23.80 \%$ \\
\hline 3 & 325 & 159 & $48.92 \%$ & 366 & 92 & $25.10 \%$ \\
\hline
\end{tabular}


Table VIII

Contagion effect analysis by event window

This table reports the cumulative abnormal returns of firms engaged in a corporate scandal (proxied by the filing of a security class action suit), and a value-weighted portfolio of the remaining firms with the same 4-digit sic code (by event year). The event year $(\mathrm{t}=0)$ is defined as the year in which the security class action suit was filed against the firm. The daily abnormal return of a security is computed by subtracting the predicted normal return (estimated using the market model) from the actual return for each day in the event window.

\begin{tabular}{|c|c|c|c|c|c|c|c|c|c|}
\hline $\begin{array}{l}\text { Day/window } \\
\text { relative to SCAS } \\
\text { filing } \\
\end{array}$ & \multicolumn{5}{|c|}{ Reaction of SCAS firms } & \multicolumn{4}{|c|}{ Reaction of PEERS } \\
\hline & $\mathrm{N}$ & $\mathrm{AR} / \mathrm{CAR}$ & $\mathrm{t}$ & $\mathrm{P}>$ & $>|t|$ & $\mathrm{N}$ & $\mathrm{AR} / \mathrm{CAR}$ & $\mathrm{t}$ & $\mathrm{P}>|\mathrm{t}|$ \\
\hline-10 & 693 & $-0.60 \%$ & -2.63 & 0.009 & $(* * *)$ & 705 & $-0.04 \%$ & -0.64 & 0.520 \\
\hline-9 & 694 & $-0.50 \%$ & -1.89 & 0.060 & $(* *)$ & 705 & $-0.05 \%$ & -0.76 & 0.448 \\
\hline-8 & 692 & $-1.11 \%$ & -4.18 & 0.000 & $(* * *)$ & 705 & $-0.04 \%$ & -0.52 & 0.602 \\
\hline-7 & 692 & $-0.90 \%$ & -3.56 & 0.000 & $(* * *)$ & 705 & $0.04 \%$ & 0.44 & 0.658 \\
\hline-6 & 693 & $-1.38 \%$ & -4.26 & 0.000 & $(* * *)$ & 705 & $-0.04 \%$ & -0.47 & 0.640 \\
\hline-5 & 692 & $-0.88 \%$ & -1.55 & 0.122 & & 705 & $-0.01 \%$ & -0.11 & 0.915 \\
\hline-4 & 693 & $-1.77 \%$ & -4.89 & 0.000 & $(* * *)$ & 705 & $-0.03 \%$ & -0.38 & 0.700 \\
\hline-3 & 693 & $-1.90 \%$ & -5.68 & 0.000 & $(* * *)$ & 705 & $-0.17 \%$ & -2.39 & $0.017(* *)$ \\
\hline-2 & 688 & $-1.68 \%$ & -3.84 & 0.000 & $(* * *)$ & 705 & $0.16 \%$ & 1.81 & $0.070\left(^{*}\right)$ \\
\hline-1 & 685 & $-3.21 \%$ & -6.81 & 0.000 & $(* * *)$ & 705 & $-0.10 \%$ & -1.35 & 0.177 \\
\hline 0 & 686 & $-2.34 \%$ & -5.17 & 0.000 & $(* * *)$ & 705 & $-0.11 \%$ & -1.64 & 0.101 \\
\hline 1 & 687 & $-1.77 \%$ & -6.42 & 0.000 & $(* * *)$ & 705 & $-0.02 \%$ & -0.21 & 0.834 \\
\hline 2 & 687 & $-0.80 \%$ & -3.30 & 0.001 & $(* * *)$ & 705 & $-0.29 \%$ & -3.68 & $0.000(* * *)$ \\
\hline 3 & 686 & $-0.49 \%$ & -1.86 & 0.063 & $(*)$ & 705 & $-0.06 \%$ & -0.86 & 0.389 \\
\hline 4 & 686 & $-0.23 \%$ & -0.83 & 0.405 & & 705 & $0.04 \%$ & 0.55 & 0.581 \\
\hline 5 & 685 & $-0.03 \%$ & -0.10 & 0.924 & & 705 & $0.02 \%$ & 0.30 & 0.761 \\
\hline 6 & 686 & $0.05 \%$ & 0.18 & 0.854 & & 705 & $-0.04 \%$ & -0.47 & 0.637 \\
\hline 7 & 686 & $-0.43 \%$ & -1.73 & 0.084 & $(*)$ & 705 & $-0.05 \%$ & -0.70 & 0.484 \\
\hline 8 & 686 & $0.21 \%$ & 0.79 & 0.431 & & 705 & $0.08 \%$ & 0.93 & 0.352 \\
\hline 9 & 686 & $-0.34 \%$ & -1.22 & 0.225 & & 705 & $-0.04 \%$ & -0.60 & 0.550 \\
\hline 10 & 687 & $-0.20 \%$ & -0.83 & 0.406 & & 705 & $-0.01 \%$ & -0.20 & 0.840 \\
\hline$[-1,0]$ & 705 & $-5.40 \%$ & -8.38 & 0.000 & $(* * *)$ & 705 & $-0.21 \%$ & -2.11 & $0.036\left(^{*}\right)$ \\
\hline$[0,+1]$ & 705 & $-4.00 \%$ & -7.80 & 0.000 & $(* * *)$ & 705 & $-0.12 \%$ & -1.27 & 0.206 \\
\hline$[-1,+1]$ & 705 & $-7.12 \%$ & -10.03 & 0.000 & $(* * *)$ & 705 & $-0.23 \%$ & -1.73 & $0.084\left(^{*}\right)$ \\
\hline$[-5,+5]$ & 705 & $-14.73 \%$ & -12.60 & 0.000 & $(* * *)$ & 705 & $-0.56 \%$ & -1.98 & $0.048(* *)$ \\
\hline$[-10,+10]$ & 705 & $-19.84 \%$ & -14.01 & 0.000 & $(* * *)$ & 705 & $-0.75 \%$ & -1.92 & $0.056\left(^{*}\right)$ \\
\hline$[-10,-2]$ & 705 & $-10.52 \%$ & -9.69 & 0.000 & $(* * *)$ & 705 & $-0.18 \%$ & -0.73 & 0.465 \\
\hline$[-10,+1]$ & 705 & $-17.64 \%$ & -14.04 & 0.000 & $(* * *)$ & 705 & $-0.41 \%$ & -1.36 & 0.173 \\
\hline$[+2,+10]$ & 705 & $-2.20 \%$ & -3.34 & 0.001 & $(* * *)$ & 705 & $-0.35 \%$ & -1.53 & 0.127 \\
\hline
\end{tabular}




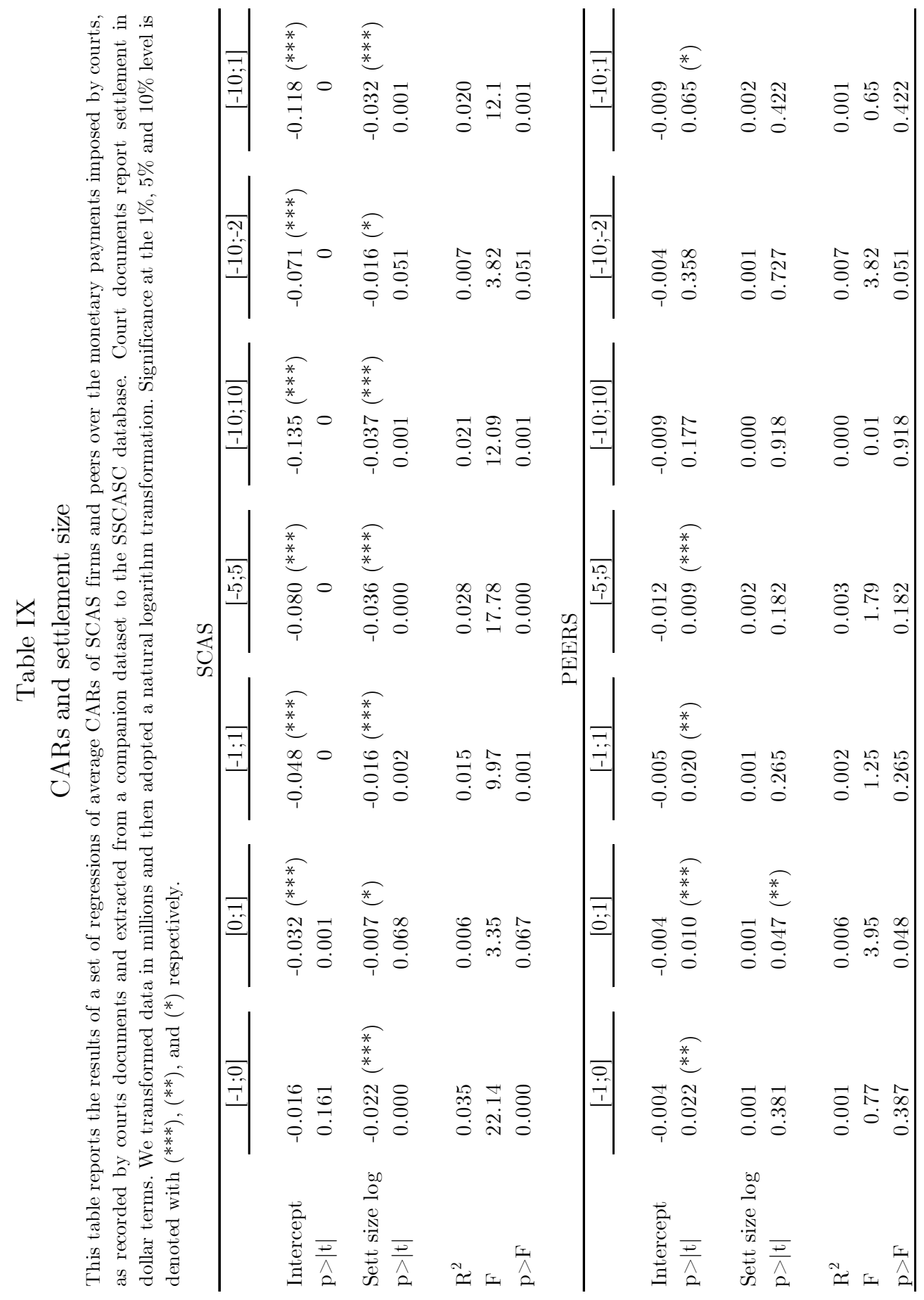




\section{Table X}

\section{Contagion effect according to leverage}

This table reports the cumulative abnormal returns of firms engaged in a corporate scandal (proxied by the filing of a security class action suit or a bankruptcy announcement), and a value-weighted portfolio of the remaining firms with the same 4-digit sic code. The sample is divided using a dummy variable equal to one if the SCAS firm was within the 51-100 percentile of book leverage. Results of the market leverage analysis are not presented but remain unchanged.

Sample A: HIGH Leverage

\begin{tabular}{|c|c|c|c|c|c|c|c|c|}
\hline \multirow[t]{2}{*}{$\begin{array}{c}\text { Day/window } \\
\text { relative to SCAS } \\
\text { filing } \\
\end{array}$} & \multicolumn{4}{|c|}{ Reaction of SCAS firms } & \multicolumn{4}{|c|}{ Reaction of PEERS } \\
\hline & $\mathrm{N}$ & $\mathrm{CAR}$ & $\mathrm{t}$ & $\mathrm{P}>|\mathrm{t}|$ & $\mathrm{N}$ & CAR & $\mathrm{t}$ & $\mathrm{P}>|\mathrm{t}|$ \\
\hline$[-1,0]$ & 242 & $-5.86 \%$ & -5.42 & $0.000(* * *)$ & 242 & $-0.21 \%$ & -1.35 & 0.178 \\
\hline$[0,+1]$ & 242 & $-3.43 \%$ & -4.59 & $0.000(* * *)$ & 242 & $-0.19 \%$ & -1.15 & 0.251 \\
\hline$[-1,+1]$ & 242 & $-7.38 \%$ & -6.68 & $0.000(* * *)$ & 242 & $-0.27 \%$ & -1.36 & 0.176 \\
\hline$[-5,+5]$ & 242 & $-13.53 \%$ & -7.24 & $0.000(* * *)$ & 242 & $-0.46 \%$ & -1.07 & 0.285 \\
\hline$[-10,+10]$ & 242 & $-18.66 \%$ & -8.04 & $0.000(* * *)$ & 242 & $-0.49 \%$ & -0.81 & 0.417 \\
\hline$[-10,-2]$ & 242 & $-8.06 \%$ & -4.42 & $0.000(* * *)$ & 242 & $-0.28 \%$ & -0.83 & 0.409 \\
\hline$[-10,+1]$ & 242 & $-15.44 \%$ & -7.54 & $0.000(* * *)$ & 242 & $-0.55 \%$ & -1.30 & 0.195 \\
\hline$[+2,+10]$ & 242 & $-3.22 \%$ & -3.05 & $0.003(* * *)$ & 242 & $0.06 \%$ & 0.17 & 0.869 \\
\hline \multicolumn{9}{|c|}{ Sample B: LOW Leverage } \\
\hline \multirow[t]{2}{*}{$\begin{array}{l}\text { Day/window } \\
\text { relative to SCAS } \\
\text { filing } \\
\end{array}$} & \multicolumn{4}{|c|}{ Reaction of SCAS } & \multicolumn{4}{|c|}{ Reaction of PEERS } \\
\hline & $\mathrm{N}$ & CAR & $\mathrm{t}$ & $\mathrm{P}>|\mathrm{t}|$ & $\mathrm{N}$ & CAR & $\mathrm{t}$ & $\mathrm{P}>|\mathrm{t}|$ \\
\hline$[-1,0]$ & 251 & $-4.95 \%$ & -4.46 & $0.000(* * *)$ & 251 & $0.00 \%$ & 0.03 & 0.979 \\
\hline$[0,+1]$ & 251 & $-4.93 \%$ & -5.31 & $0.000(* * *)$ & 251 & $-0.02 \%$ & -0.13 & 0.896 \\
\hline$[-1,+1]$ & 251 & $-6.93 \%$ & -5.67 & $0.000(* * *)$ & 251 & $-0.03 \%$ & -0.17 & 0.865 \\
\hline$[-5,+5]$ & 251 & $-14.45 \%$ & -7.20 & $0.000(* * *)$ & 251 & $-0.71 \%$ & -1.80 & $0.074(*)$ \\
\hline$[-10,+10]$ & 251 & $-20.20 \%$ & -8.39 & $0.000(* * *)$ & 251 & $-0.77 \%$ & -1.28 & 0.203 \\
\hline$[-10,-2]$ & 251 & $-12.14 \%$ & -6.95 & $0.000(* * *)$ & 251 & $-0.57 \%$ & -1.67 & $0.097\left(^{*}\right)$ \\
\hline$[-10,+1]$ & 251 & $-19.06 \%$ & -8.83 & $0.000(* * *)$ & 251 & $-0.61 \%$ & -1.62 & 0.107 \\
\hline$[+2,+10]$ & 251 & $-1.13 \%$ & -1.01 & 0.315 & 251 & $-0.16 \%$ & -0.42 & 0.674 \\
\hline
\end{tabular}




\section{Table XI}

\section{Contagion effect and correlation of stock returns}

This table reports the cumulative abnormal returns of firms engaged in a corporate scandal (proxied by the filing of a security class action suit), and a value-weighted portfolio of the remaining firms with the same 4-digit sic code (by event year). The event year $(t=0)$ is defined as the year in which the security class action suit was filed against the firm. The daily abnormal return of a security is computed by subtracting the predicted normal return (estimated using the market model) from the actual return for each day in the event window. The high/low correlation of returns dummy is defined as: 0 if correlations of returns (between SCAS and PEERS in the year preceding the filing) lies within the [1-50th] percentile and 1 if it lies within the [51-100]th percentile in the year before the filing of the SCAS.

Sample A: HIGH correlation of returns

$\mathrm{Day} /$ window relative to SCAS filing Reaction of SCAS firms

Reaction of PEERS

\begin{tabular}{|c|c|c|c|c|c|c|c|c|}
\hline & $\mathrm{N}$ & $\mathrm{AR} / \mathrm{CAR}$ & $\mathrm{t}$ & $\mathrm{P}>|\mathrm{t}|$ & $\mathrm{N}$ & $\mathrm{AR} / \mathrm{CAR}$ & $\mathrm{t}$ & $\mathrm{P}>|\mathrm{t}|$ \\
\hline$[-1,0]$ & 344 & $-5.99 \%$ & -6.71 & $0.000(* * *)$ & 344 & $-0.21 \%$ & -1.68 & $0.093(*)$ \\
\hline$[0,+1]$ & 344 & $-3.91 \%$ & -5.18 & $0.000(* * *)$ & 344 & $-0.13 \%$ & -0.88 & 0.379 \\
\hline$[-1,+1]$ & 344 & $-7.31 \%$ & -7.34 & $0.000(* * *)$ & 344 & $-0.24 \%$ & -1.32 & 0.188 \\
\hline$[-5,+5]$ & 344 & $-14.69 \%$ & -9.70 & $0.000(* * *)$ & 344 & $-0.72 \%$ & -2.00 & $0.046(* *)$ \\
\hline$[-10,+10]$ & 344 & $-18.74 \%$ & -9.98 & $0.000(* * *)$ & 344 & $-0.94 \%$ & -1.71 & $0.089(*)$ \\
\hline$[-10,-2]$ & 344 & $-10.56 \%$ & -7.86 & $0.000(* * *)$ & 344 & $-0.54 \%$ & -1.84 & $0.067\left(^{*}\right)$ \\
\hline$[-10,+1]$ & 344 & $-17.88 \%$ & -10.62 & $0.000(* * *)$ & 344 & $-0.77 \%$ & -2.10 & $0.036(* *)$ \\
\hline$[+2,+10]$ & 344 & $-0.86 \%$ & -1.09 & 0.278 & 344 & $-0.16 \%$ & -0.48 & 0.629 \\
\hline \multicolumn{9}{|c|}{ Sample B: LOW correlation of returns } \\
\hline \multirow[t]{2}{*}{$\begin{array}{c}\text { Day/windo } \\
\text { relative to } \mathrm{SC} \\
\text { filing }\end{array}$} & \multicolumn{4}{|c|}{ Reaction of SCAS firms } & \multicolumn{4}{|c|}{ Reaction of PEERS } \\
\hline & $\mathrm{N}$ & $\mathrm{AR} / \mathrm{CAR}$ & $\mathrm{t}$ & $\mathrm{P}>|\mathrm{t}|$ & $\mathrm{N}$ & $\mathrm{AR} / \mathrm{CAR}$ & $\mathrm{t}$ & $\mathrm{P}>|\mathrm{t}|$ \\
\hline$[-1,0]$ & 361 & $-4.83 \%$ & -5.22 & $0.000(* * *)$ & 361 & $-0.21 \%$ & -1.37 & 0.173 \\
\hline$[0,+1]$ & 361 & $-4.09 \%$ & -5.86 & $0.000(* * *)$ & 361 & $-0.12 \%$ & -0.91 & 0.365 \\
\hline$[-1,+1]$ & 361 & $-6.94 \%$ & -6.86 & $0.000(* * *)$ & 361 & $-0.22 \%$ & -1.14 & 0.256 \\
\hline$[-5,+5]$ & 361 & $-14.77 \%$ & -8.34 & $0.000(* * *)$ & 361 & $-0.40 \%$ & -0.94 & 0.349 \\
\hline$[-10,+10]$ & 361 & $-20.89 \%$ & -9.9 & $0.000(* * *)$ & 361 & $-0.58 \%$ & -1.03 & 0.304 \\
\hline$[-10,-2]$ & 361 & $-10.49 \%$ & -6.19 & $0.000(* * *)$ & 361 & $0.16 \%$ & 0.40 & 0.687 \\
\hline$[-10,+1]$ & 361 & $-17.42 \%$ & -9.37 & $0.000(* * *)$ & 361 & $-0.06 \%$ & -0.12 & 0.901 \\
\hline$[+2,+10]$ & 361 & $-3.46 \%$ & -3.36 & $0.001(* * *)$ & 361 & $-0.52 \%$ & -1.71 & 0.088 \\
\hline
\end{tabular}


Table XII

Determinants of security offerings

In this table we test the robustness of previous results controlling for alternative determinants of Capital Structure. We run a set of Multivariate Fixed Effects regressions taking the the following functional form: $\mathrm{Yi}=\alpha+\beta_{1}$ GROUP $+\beta_{2}$ EVENT $+\beta_{3}$ GROUP $*$ EVENT $+\beta_{4}$ MTBi $+\beta_{6}$ LogSize ${ }_{i}+\beta_{6}$ EBITDA $/ T A i+\beta_{7}$ PPE $/$ TA ${ }_{i}+\beta_{8} B e t a+F E+\varepsilon$, where Yi is the dependent variable capturing Total issuance, Equity issuance or Debt issuance, GROUP is the group operator taking value of 1 for SCAScompanies an 0 otherwise, EVENT is the time operator taking value of one for pre-filing figures and 0 for postfiling observations, GROUP*EVENT is the interaction term, MTB is the Market-to-Book ratio, beta is the risk of the company measured by the average stock beta, LogSIZE is the natural logarithm market capitalization of the company and EBITDA/TA is the ratio of EBITDA over Total Assets, PPE/TA is the level of Fixed Assets scaled by Total assets and Beta is the CRSP market Beta. All independent variables are calculated as average values before and after the filing. Robust standard error are reported in parntheses. Significance at the $1 \%, 5 \%$ and $10 \%$ level is denoted by $* * *, * *, *$ respectively.

\begin{tabular}{|c|c|c|c|c|c|c|}
\hline \multirow[b]{2}{*}{ Dependent variable } & \multicolumn{3}{|c|}{ SCAS and Peers sample } & \multicolumn{3}{|c|}{ Peers Only } \\
\hline & $\begin{array}{c}\text { Total Security } \\
\text { offerings }\end{array}$ & $\begin{array}{c}\text { Equity } \\
\text { offerings }\end{array}$ & Debt offerings & $\begin{array}{c}\text { Totale } \\
\text { Security }\end{array}$ & $\begin{array}{c}\text { Equity } \\
\text { offerings }\end{array}$ & Debt offerings \\
\hline Intercept & $\begin{array}{c}0.250^{* * *} \\
(2.93)\end{array}$ & $\begin{array}{c}0.254^{* * *} \\
(3.30)\end{array}$ & $\begin{array}{l}-0.003 \\
(-0.11)\end{array}$ & $\begin{array}{c}0.150^{* * *} \\
(6.00)\end{array}$ & $\begin{array}{c}0.120^{* * *} \\
(9.36)\end{array}$ & $\begin{array}{l}0.033^{*} \\
(1.89)\end{array}$ \\
\hline Group & $\begin{array}{c}-0.069 * * \\
(-2.42)\end{array}$ & $\begin{array}{l}-0.028 \\
(-1.59)\end{array}$ & $\begin{array}{c}-0.045^{* *} \\
(-2.52)\end{array}$ & & & \\
\hline Event & $\begin{array}{c}0.032^{* * *} \\
(3.07)\end{array}$ & $\begin{array}{c}0.019^{* * *} \\
(3.05)\end{array}$ & $\begin{array}{c}0.013^{* *} \\
(1.97)\end{array}$ & & & \\
\hline Group*Event & $\begin{array}{c}0.336^{* * *} \\
(6.44)\end{array}$ & $\begin{array}{c}0.211^{* * *} \\
(5.53)\end{array}$ & $\begin{array}{c}0.127^{* * *} \\
(4.33)\end{array}$ & & & \\
\hline MTB & $\begin{array}{l}-0.000 \\
(-0.29)\end{array}$ & $\begin{array}{l}-0.001 \\
(-0.49)\end{array}$ & $\begin{array}{l}0.000 \\
(0.91)\end{array}$ & $\begin{array}{c}0.002^{* *} \\
(2.43)\end{array}$ & $\begin{array}{c}0.001^{* *} \\
(2.55)\end{array}$ & $\begin{array}{l}0.000 \\
(1.19)\end{array}$ \\
\hline LogSize & $\begin{array}{c}-0.032^{* *} \\
(-2.32)\end{array}$ & $\begin{array}{c}-0.036^{* * *} \\
(-3.03)\end{array}$ & $\begin{array}{l}0.000 \\
(0.80)\end{array}$ & $\begin{array}{c}-0.013^{* * *} \\
(-3.67)\end{array}$ & $\begin{array}{c}-0.014^{* * *} \\
(-6.95)\end{array}$ & $\begin{array}{l}0.000 \\
(0.39)\end{array}$ \\
\hline EBITDA/TA & $\begin{array}{l}-0.019 \\
(-1.43)\end{array}$ & $\begin{array}{c}-0.011^{*} \\
(-1.71)\end{array}$ & $\begin{array}{l}-0.009 \\
(-0.89)\end{array}$ & $\begin{array}{c}0.003^{* * *} \\
(3.21)\end{array}$ & $\begin{array}{l}-0.000 \\
(-1.25)\end{array}$ & $\begin{array}{c}0.004^{* * *} \\
(5.13)\end{array}$ \\
\hline $\mathrm{PPE} / \mathrm{TA}$ & $\begin{array}{l}-0.005 \\
(-0.58)\end{array}$ & $\begin{array}{l}-0.007 \\
(-1.19)\end{array}$ & $\begin{array}{l}0.002 \\
(0.49)\end{array}$ & $\begin{array}{l}-0.000 \\
(-0.30)\end{array}$ & $\begin{array}{c}-0.003^{*} \\
(-1.88)\end{array}$ & $\begin{array}{c}0.003^{* *} \\
(2.28)\end{array}$ \\
\hline Beta & $\begin{array}{l}0.039 \\
(0.75)\end{array}$ & $\begin{array}{l}0.049 \\
(1.49)\end{array}$ & $\begin{array}{l}-0.009 \\
(-0.39)\end{array}$ & $\begin{array}{c}0.037^{* * *} \\
(2.69)\end{array}$ & $\begin{array}{c}0.040^{* * *} \\
(4.89)\end{array}$ & $\begin{array}{l}-0.006 \\
(-0.63)\end{array}$ \\
\hline Industry Fixed effects & YES & YES & YES & YES & YES & YES \\
\hline $\mathrm{N}$ & 2385 & 2385 & 2389 & 1331 & 1331 & 1331 \\
\hline $\mathrm{R}^{2}$ & 0.075 & 0.096 & 0.022 & 0.257 & 0.291 & 0.237 \\
\hline $\mathrm{F}$ & 15.25 & 17.30 & 5.852 & 4.967 & 12.69 & 7.669 \\
\hline
\end{tabular}




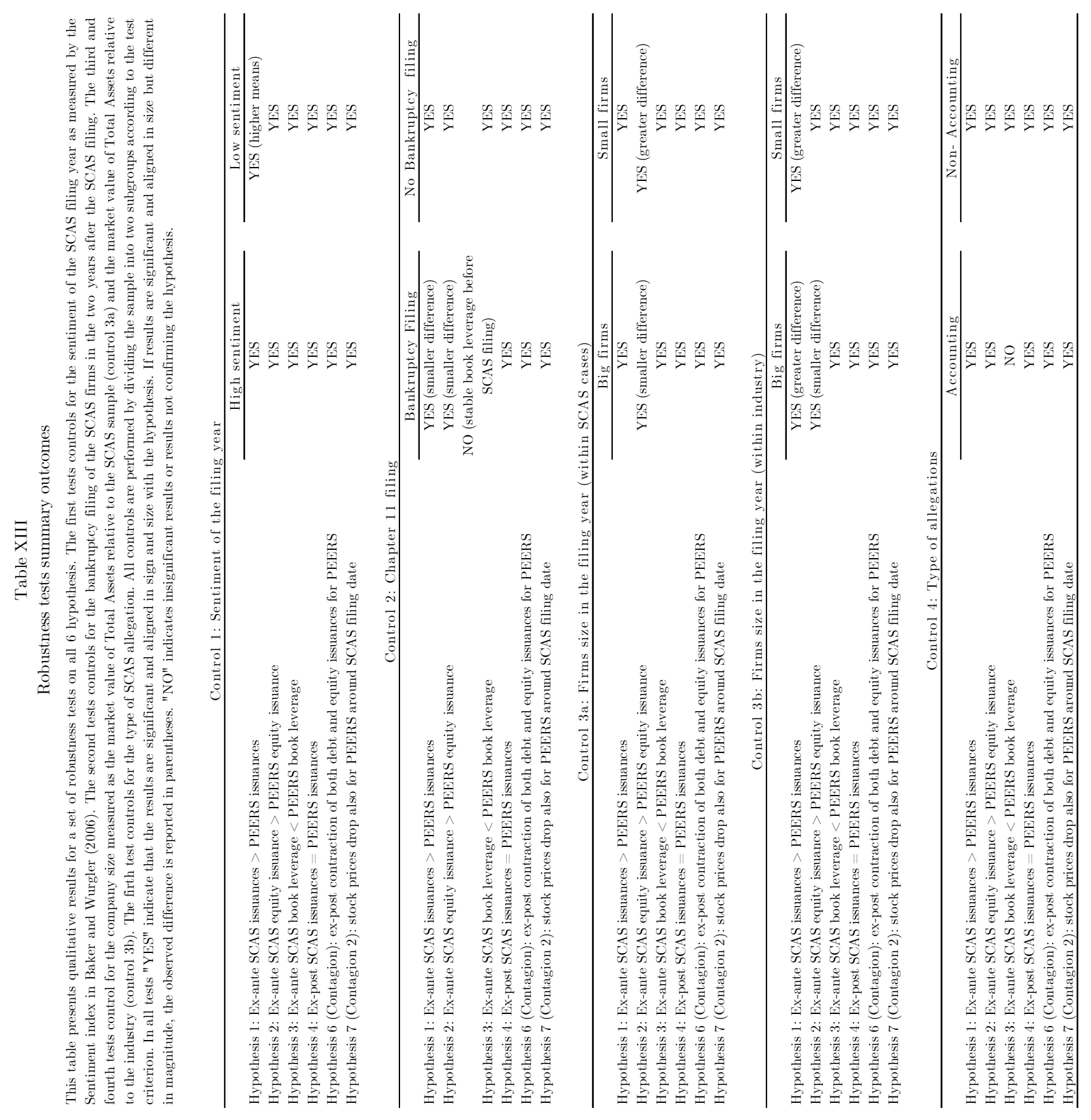




\section{Figure I}

Total security offerings trend analysis

This figure reports the results of the regression: $Y_{j t}=\alpha_{j}+\beta_{j}(T)+\varepsilon_{j t}$; where, $Y_{j t}$ are total security issuances, $\mathrm{T}$ is a trend variable that ranges from $\{1,6\}$, and $\varepsilon_{\mathrm{jt}}$ is the error term of the regression. The amount of total-yearly- security offerings is measured as the sum of debt issuances and book equity issuances.

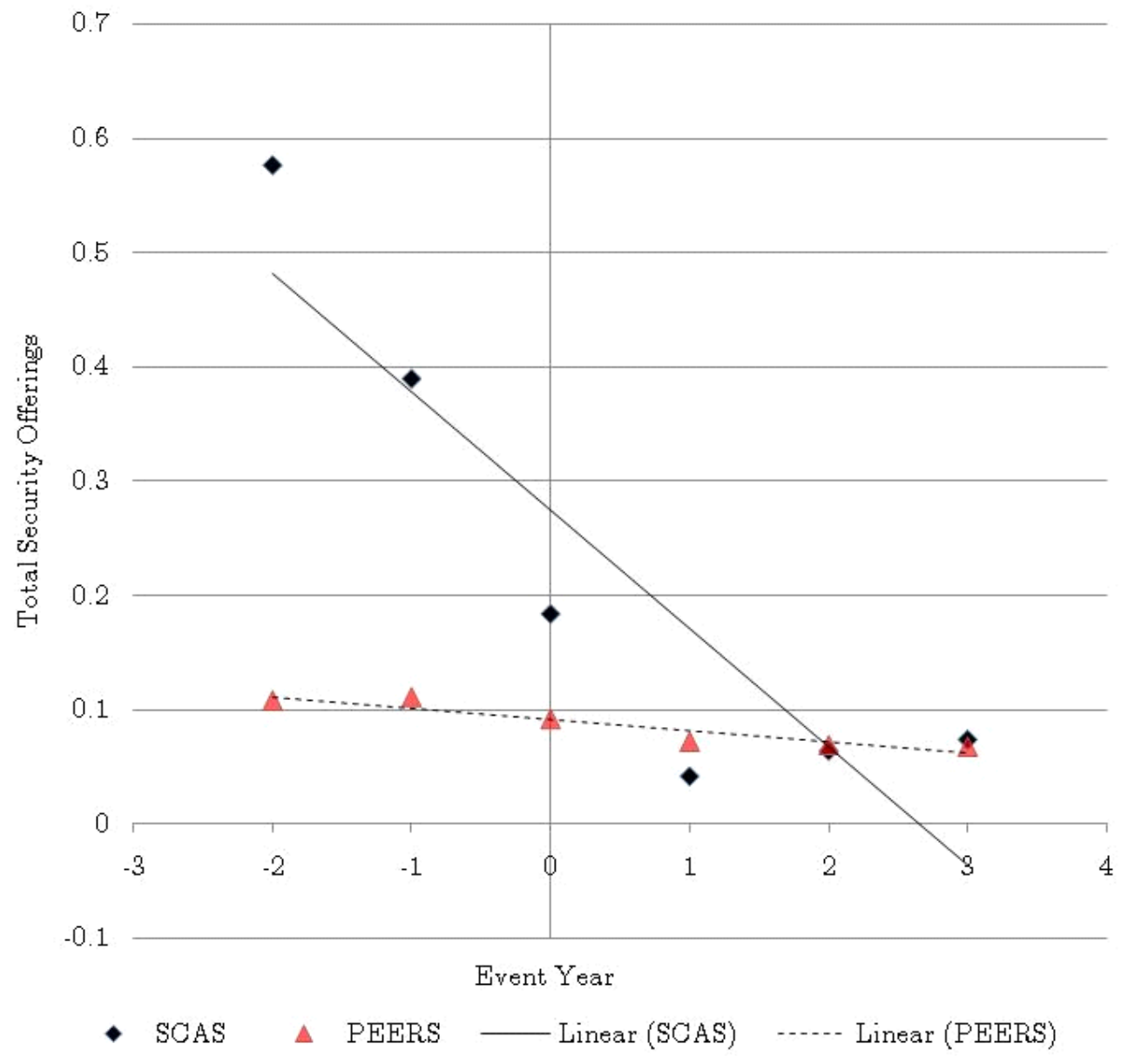




\section{Figure II}

Equity and Debt issuance trend analysis

This figure reports the results of the regression: $Y_{j t}=\alpha_{j}+\beta_{j}(T)+\varepsilon_{j t}$; where, $Y_{j t}$ are either equity, debt or total security issuances, $T$ is a trend variable that ranges from $\{1,6\}$, and $\varepsilon_{j \mathrm{t}}$ is the error term of the regression. Debt issuances are measured as the change in total assets minus change in book equity divided by total assets. Book equity issuances are measured as the change in book equity minus the change in balance sheet retained earnings, divided by total assets.

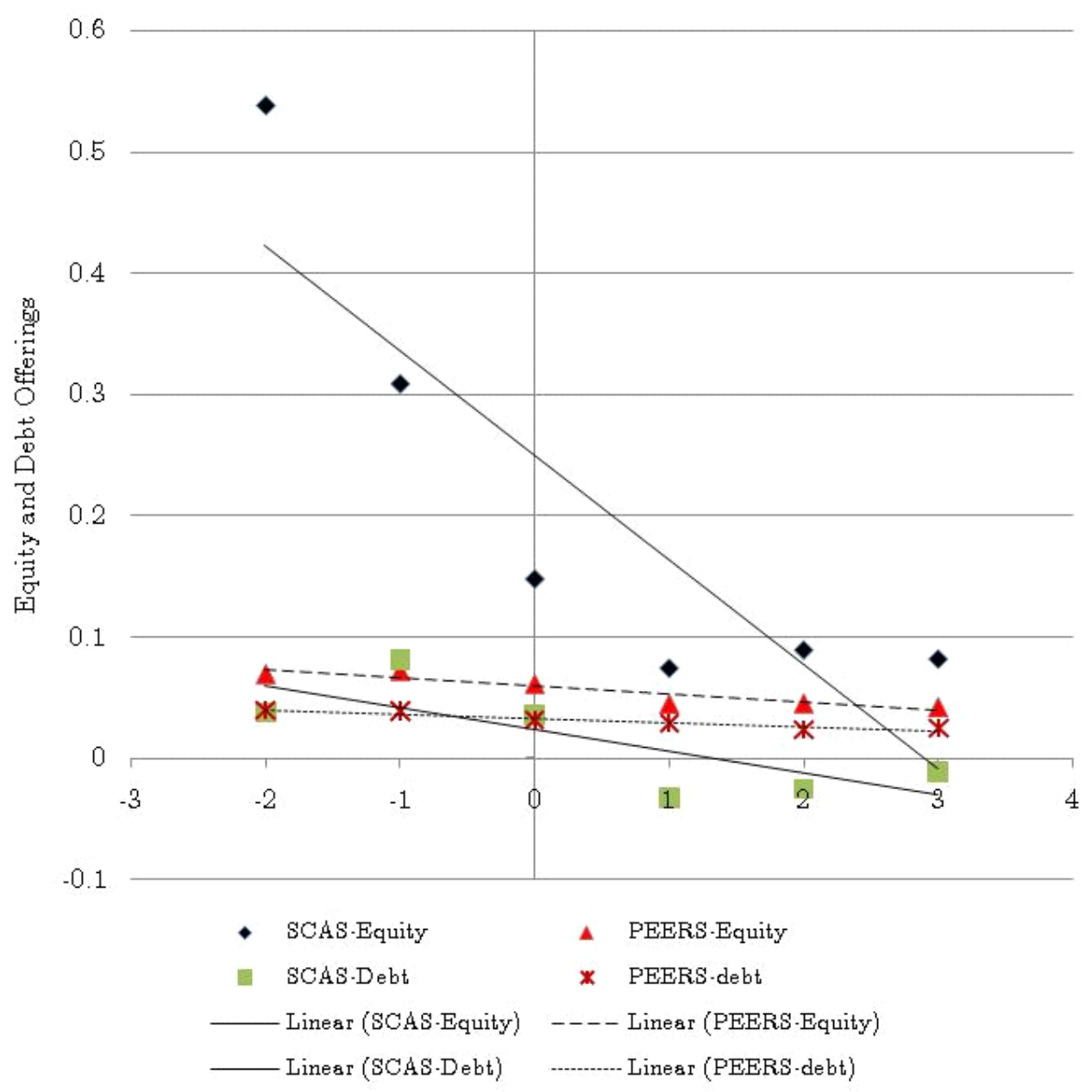


Figure III

Ratings and rating changes

This figure reports the average rating of SCAS companies over the period $\{-3 ; 3\}$ where 0 is the SCAS filing event date, the relative frequencies of rating yearly changes and the T-test for difference in the sample's rating means before and after the event. The average yearly rating is plotted by the solid line on the right axis scale; the relative frequencies of rating changes for the five different notch change classes are measured by the bar stacks on the left axis scale; the notch change classes measure rating changes on the same company in two contiguous dates and read as follows: " $\leq-2$ " indicating a two or more notches downgrading; "-1" indicating a one notch downgrading; "0" indicating a confirmed rating; "1" indicating a one notch upgrading; " $\geq 2$ " indicating a positive two or more notch upgrading. Difference in the means are tested against the null hypothesis of no difference. Significance at the 1,5 and $10 \%$ level is denoted by $* * *{ }^{* *}$, and ${ }^{*}$ respectively.

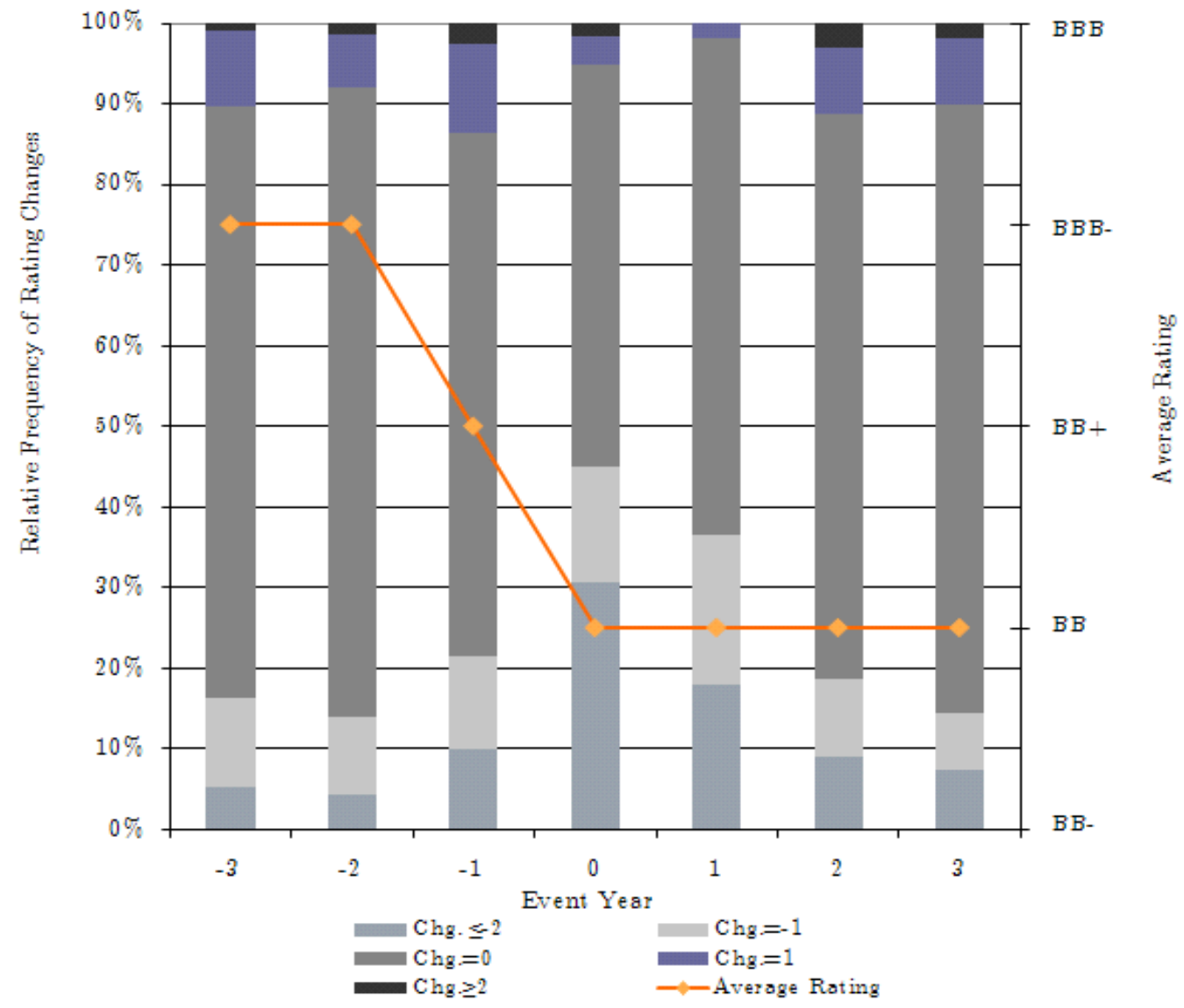

\begin{tabular}{|c|c|c|c|c|c|c|}
\hline Variable & Obs & Mean & $\begin{array}{c}\text { Mean } \\
(\text { diff })\end{array}$ & $\operatorname{Pr}(|\mathrm{T}|>|\mathrm{t}|)^{(1)}$ & $\operatorname{Pr}(\mathrm{T}>\mathrm{t})^{(2)}$ & $\operatorname{Pr}(\mathrm{T}<\mathrm{t})^{(3)}$ \\
\hline $\begin{array}{l}\text { SCAS companies } \\
\text { rating before the } \\
\text { SCAS filing }\end{array}$ & 3205 & $\begin{array}{l}10.789 \\
(\mathrm{BB}+)\end{array}$ & & & & \\
\hline $\begin{array}{l}\text { SCAS companies } \\
\text { rating before the } \\
\text { SCAS filing }\end{array}$ & 3119 & $11.891(\mathrm{BB})$ & -1.102 & $0.000(* * *)$ & 1.000 & $0.000(* * *)$ \\
\hline
\end{tabular}

\footnotetext{
${ }^{(1)} \mathrm{Ha}:$ mean $($ diff $) \neq 0$

${ }^{(2)} \mathrm{Ha}: \operatorname{mean}($ diff $)>0$

${ }^{(3)} \mathrm{Ha}$ : mean (diff) $<0$
} 


\section{Figure IV}

\section{SCAS, Dismissed and Industry security issuance}

This figure plots security issuances for SCAS companies, the Industry peers and the Dismissed control group. Dots represent the actual amount of total security issuance (Debt and equity). Zero represent the event year.

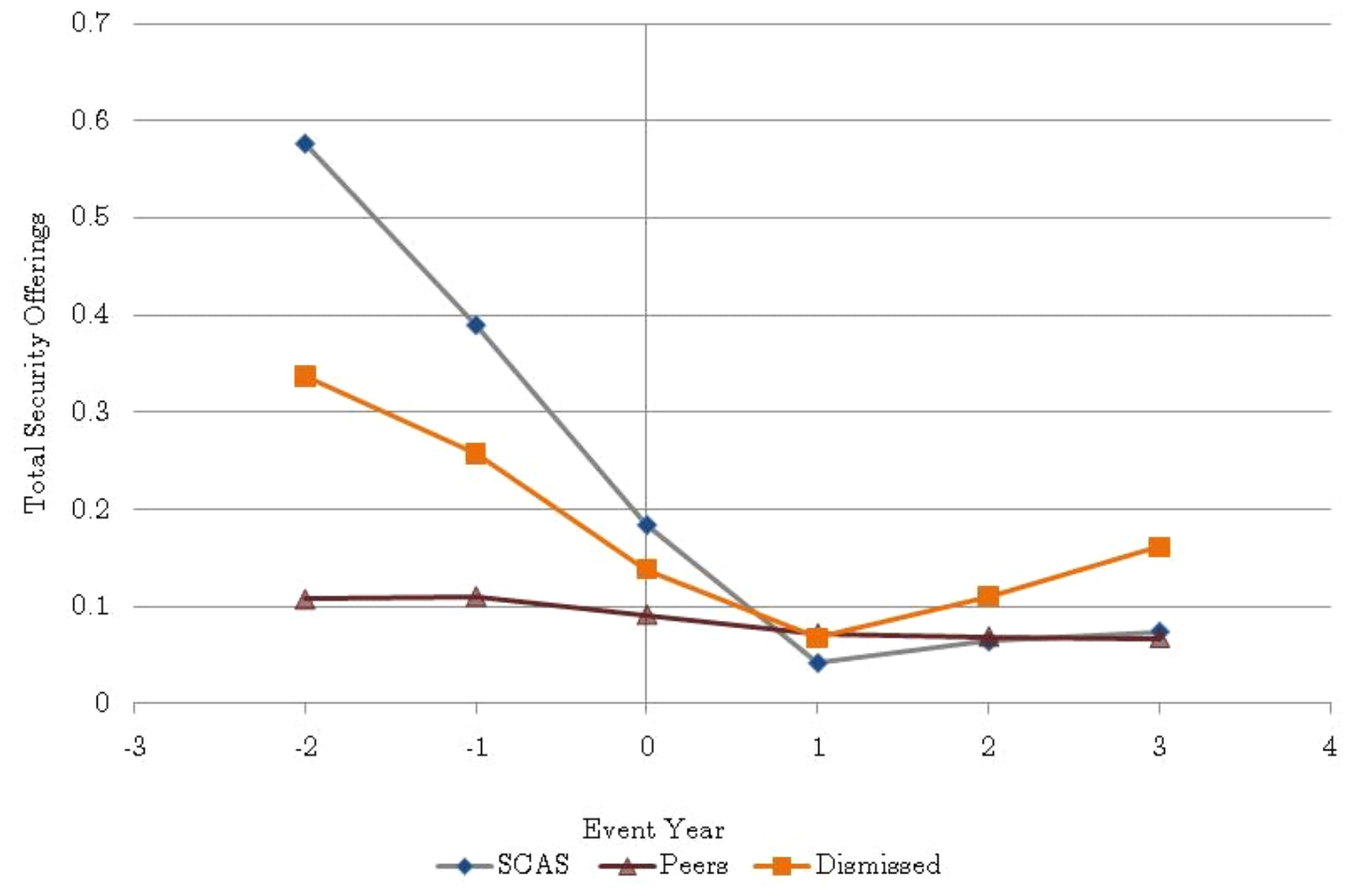




\section{Internet Appendix 1}

We argue that managers in companies involved in a security class action - which eventually detects a fraudulent behaviour - have an incentive to incur the risk of imperfect information disclosure because full information revelation would increase their financing costs, reduce managerial flexibility and, most importantly, reduce the amount of resources available to pursue activities as investments, research and development expenses and acquisitions. These activities are typical paths for fast growth but also possible sources of overinvestment (Hubbard, 1998) and "empire building" (Jensen, 1986). This behaviour is likelier in companies where comparatively weaker governance increases agency costs. SCAS filings provide anecdotal but widespread evidence of such costs. We support this view by looking at the M\&A activity, R\&D expenditures and Dividends disbursment by SCAS companies.

Results reported in Tables A1 show that companies sued by securityholders show a much higher volume of acquisitions compared to similar companies in the same industry as measured by the four-digits SIC code. In particular SCAS companies complete an average of 4 acquisitions per year which is twice the industry average. Similarly, the average dollar value of yearly acquisitions is approximately 6 times larger than that of the competitors. This pattern however subside and reverts to the industry mean after the class action filing suggesting that the abnormal pre-filing activity was likely excessive.

\section{INSERT TABLE A1-1 HERE}

Similarly, R\&D expenses grow at an abnormally high rate before the class action. Once the scandal is revealed, R\&D growth falls sharply and quickly below the industry level and eventually is not statistically different from that of the peers group.

\section{INSERT TABLE A2-1 HERE}

This level of overinvestment is possibly allowed by weaker governance in SCAS companies. Standard financial theory has highlighted that dividends are costly to the firm as they reduce the amount of cash available for precautionary and investment

purposes. However, dividends have strong signalling effects and actual payout levels are set according to a complex set of information and signals (John and Kalay, 1982, Miller 
and Rock, 1985, Jensen,1986). Harford, Mansi and Maxwell (2008) suggest that when firms have weak governance mechanisms, agency costs are higher and are associated with low levels of dividends and dividend growth. Figures in Table A1 and A2 provided clear evidence of overinvestment. Results reported in Table A3, support the agency cost view by showing that SCAS companies consistently exhibit lower dividend yields when compared with their industry peers. Yields are most often close to zero and grow only after the scandal eruption.

INSERT TABLE A3-1 HERE 


\section{Internet Appendix 2}

\section{Contagion effect and cash flow similarity}

Hypothesis 6 argued that if a contagion for capital structure decisions exists, it should be larger when the similarity of companies' cash flows is higher. To test this hypothesis, we estimate similarity as the correlation of returns between the industry portfolio and the firms engaged in the corporate scandal for the year preceding the filing of the class action suit. We then define a dummy variable as equal to one if the correlation of returns between the industry portfolio and the firms engaged in the corporate scandal for the year preceding the filing of the class action suit falls within the 51st and 100th percentile (high correlation) or as zero otherwise (low correlation). Table VII presents results for the peer group sorted by the degree of similarity to the relevant SCAS company. The results are statistically significant at all levels and indicate that security issuance opportunities are positively affected by corporate events in the industry when the degree of cash flow similarity between the sued company and its peers is higher. This result is twice as strong for equity as it is for debt, suggesting that shareholders sharply react, reducing financing opportunities or increasing their cost for any company in the same industry niche.

\section{INSERT TABLE A2-1 HERE}

\section{Accounting and non-accounting allegations}

The effects of a SCAS filing on capital structure decisions of peers may be interpreted as a long-term negative outlook on the industry conditional on the type of information revealed by the SCAS filing. These effects are slow to occur and translate into reduced capital-raising for both SCAS firms and their peers. Shorter-term effects, on the other hand, should increase in size and significance conditional on the likelihood of observing an event in other firms in the industry. A simple test of this concept can be performed by dividing the sample into two subsets based on the type of allegations. The information available from the SCASSC database allows only for a coarse breakdown between "accounting-related" and "non-accounting-related" allegations. Following our argument, we should observe larger price reactions both for SCAS firms and for their

peers for accounting-related allegations. In fact, non-accounting-related allegations can 
be highly firm-specific, and although they may convey a medium-to-long-term signal regarding industry status, they are less likely to have immediate effects on prices. On the other hand, accounting allegations may indicate that deteriorated industry conditions have induced the management to defer the revelation of the true financial situation. Investors may assume this behavior to be widespread among competitors determing a direct adjustment in prices.. Table XIII reports the results for this test. Price reactions to accounting-related filings are the strongest, with SCAS firm prices dropping by $-22.85 \%$ on average in the $[-1-, 10]$ window and peers similarly yielding a $-1.25 \%$ negative and significant return over the same window. As expected, the results for non-accounting-related class actions are milder and less significant.

INSERT TABLE A2-2 HERE 
Table A1-1

M\&A activity by event year

This table reports the mean number and dollar value of M\&A transaction of firms involved in a corporate scandal and the peers group. PANEL A reports figures for the absolute average number of transactions and PANEL B for the absolute dollar value of those transactions. The control group is a value-weighted portfolio of firms within the same 4-digit sic code (by event year). The bottom table report the paired t-test for the differences in event years. The null hypothesis is of zero difference in the means. The event year $\mathrm{t}=0$ is the year in which the security class action suit was filed against the firm. The last two columns of the table present the results of the one and two-tailed mean-difference tests. ***,** and $*$ denoted $1 \%, 5 \%$ and $10 \%$ significance respectively.

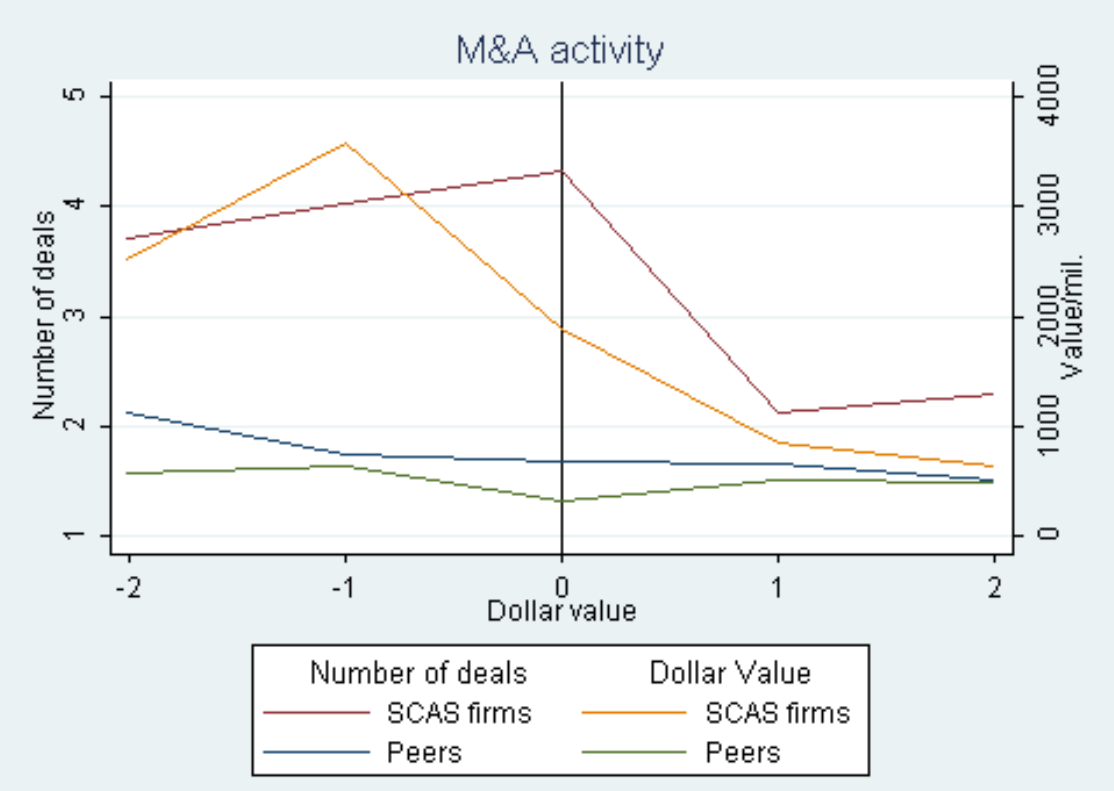

PANEL A - M\&A deals by number

\begin{tabular}{|c|c|c|c|c|c|c|}
\hline $\mathrm{t}$ & Variable & Obs & Mean & Mean(diff) & $\operatorname{Pr}(|\mathrm{T}|>|\mathrm{t}|)^{(1)}$ & $\operatorname{Pr}(\mathrm{T}>\mathrm{t})^{(2)}$ \\
\hline-2 & Number of M\&A deals completed by SCAS & 411 & 3.706 & & & \\
\hline-2 & Number of M\&A deals completed by PEERS & 411 & 2.129 & 1.578 & $0.000(* * *)$ & $0.000(* * *)$ \\
\hline-1 & Number of M\&A deals completed by SCAS & 467 & 4.020 & & & \\
\hline-1 & Number of M\&A deals completed by PEERS & 467 & 1.743 & 2.277 & $0.000(* * *)$ & $0.000(* * *)$ \\
\hline 0 & Number of M\&A deals completed by SCAS & 284 & 4.332 & & & \\
\hline 0 & Number of M\&A deals completed by PEERS & 284 & 1.678 & 2.654 & $0.000(* * *)$ & $0.000(* * *)$ \\
\hline 1 & Number of M\&A deals completed by SCAS & 173 & 2.112 & & & \\
\hline 1 & Number of M\&A deals completed by PEERS & 173 & 1.656 & 0.457 & $0.000(* * *)$ & $0.000(* * *)$ \\
\hline 2 & Number of M\&A deals completed by SCAS & 287 & 2.291 & & & \\
\hline 2 & Number of M\&A deals completed by PEERS & 287 & 1.507 & 0.784 & $0.000(* * *)$ & $0.000(* * *)$ \\
\hline
\end{tabular}

PANEL B - M\&A deals by volume

\begin{tabular}{|c|c|c|c|c|c|c|}
\hline $\mathrm{t}$ & Variable & Obs & Mean & Mean(diff) & $\operatorname{Pr}(|\mathrm{T}|>|\mathrm{t}|)^{(1)}$ & $\operatorname{Pr}(\mathrm{T}>\mathrm{t})^{(2)}$ \\
\hline-2 & Number of M\&A deals completed by SCAS & 411 & 2517.4 & & & \\
\hline-2 & Number of M\&A deals completed by PEERS & 411 & 574.6 & 1942.1 & $0.000(* * *)$ & $0.000(* * *)$ \\
\hline-1 & Number of M\&A deals completed by SCAS & 467 & 3591.9 & & & \\
\hline-1 & Number of M\&A deals completed by PEERS & 467 & 624.6 & 2967.4 & $0.000(* * *)$ & $0.000(* * *)$ \\
\hline 0 & Number of M\&A deals completed by SCAS & 284 & 1893.3 & & & \\
\hline 0 & Number of M\&A deals completed by PEERS & 284 & 322.9 & 1570.3 & $0.000(* * *)$ & $0.000(* * *)$ \\
\hline 1 & Number of M\&A deals completed by SCAS & 173 & 850.7 & & & \\
\hline 1 & Number of M\&A deals completed by PEERS & 173 & 495.7 & 355.0 & $0.027(* *)$ & $0.014(* *)$ \\
\hline 2 & Number of M\&A deals completed by SCAS & 287 & 630.3 & & & \\
\hline 2 & Number of M\&A deals completed by PEERS & $287^{54}$ & 474.6 & 155.7 & 0.188 & $0.094(*)$ \\
\hline
\end{tabular}

\footnotetext{
${ }^{(1)} \mathrm{Ha}$ : mean $($ diff $) \neq 0$
}

${ }^{(2)} \mathrm{Ha}$ : mean (diff) $>0$ 
Table A1-2

R\&D expenses growth by event year

This table reports the R\&D expenses growth rate for companies involved in a security class action and the peers group. The control group is a value-weighted portfolio of firms within the same 4-digit sic code (by event year). The bottom table report the paired t-test for the differences in event years. The null hypothesis is of zero difference in the means. The event year $t=0$ is the year in which the security class action suit was filed against the firm. The last two columns of the table present the results of the one and two-tailed mean-difference tests. ${ }^{* *},{ }^{* *}$ and ${ }^{*}$ denoted $1 \%, 5 \%$ and $10 \%$ significance respectively.

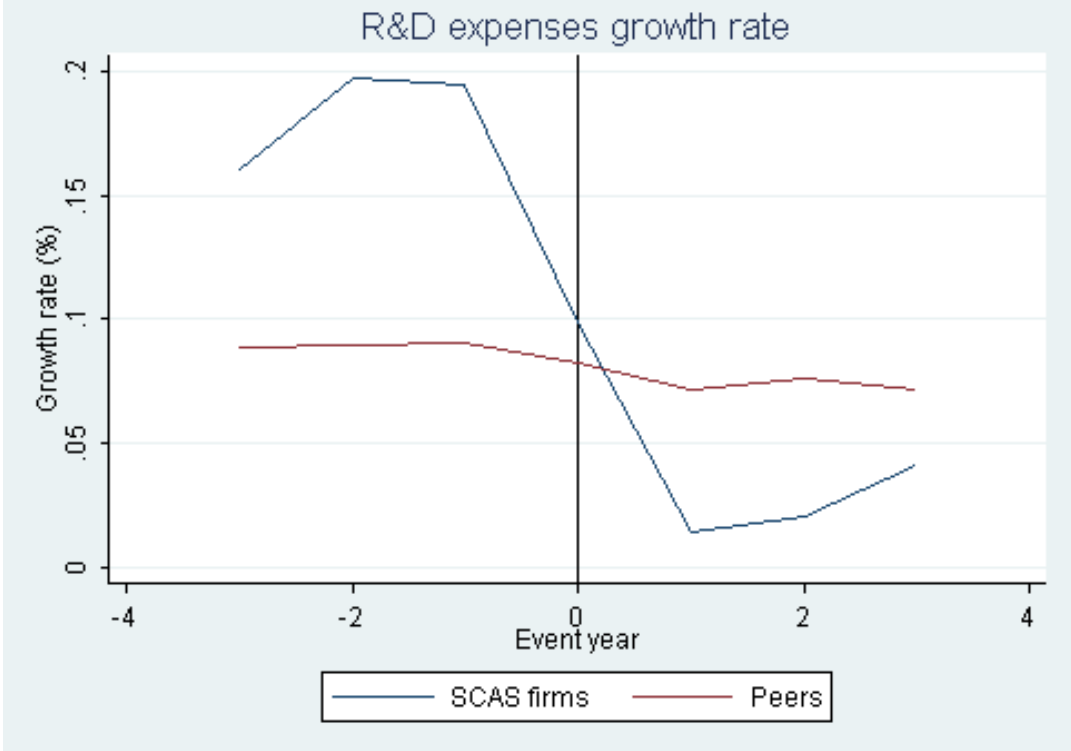

R\&D expenses yearly growth rate

\begin{tabular}{|c|c|c|c|c|c|c|}
\hline $\mathrm{t}$ & Variable & Obs & Mean & Mean(diff) & $\operatorname{Pr}(|\mathrm{T}|>|\mathrm{t}|)^{(1)}$ & $\operatorname{Pr}(\mathrm{T}>\mathrm{t})^{(2)}$ \\
\hline-3 & R\&D expenses growth rate for SCAS firms & 562 & 0.190 & & & \\
\hline-3 & R\&D expenses growth rate for PEERS firms & 562 & 0.089 & 0.101 & $0.000(* * *)$ & $0.000(* * *)$ \\
\hline-2 & R\&D expenses growth rate for SCAS firms & 604 & 0.224 & & & \\
\hline-2 & R\&D expenses growth rate for PEERS firms & 604 & 0.090 & 0.135 & $0.000(* * *)$ & $0.000(* * *)$ \\
\hline-1 & R\&D expenses growth rate for SCAS firms & 587 & 0.227 & & & \\
\hline-1 & R\&D expenses growth rate for PEERS firms & 587 & 0.091 & 0.136 & $0.000(* * *)$ & $0.000(* * *)$ \\
\hline 0 & R\&D expenses growth rate for SCAS firms & 523 & 0.116 & & & \\
\hline 0 & R\&D expenses growth rate for PEERS firms & 523 & 0.082 & 0.034 & $0.042(* *)$ & $0.021(* *)$ \\
\hline 1 & R\&D expenses growth rate for SCAS firms & 458 & 0.017 & & & \\
\hline 1 & R\&D expenses growth rate for PEERS firms & 458 & 0.072 & -0.055 & $0.000(* * *)$ & 0.999 \\
\hline 2 & R\&D expenses growth rate for SCAS firms & 410 & 0.022 & & & \\
\hline 2 & R\&D expenses growth rate for PEERS firms & 410 & 0.076 & -0.054 & $0.000(* * *)$ & 0.999 \\
\hline 3 & R\&D expenses growth rate for SCAS firms & 335 & 0.049 & & & \\
\hline 3 & R\&D expenses growth rate for PEERS firms & 335 & 0.071 & -0.023 & 0.207 & 0.897 \\
\hline
\end{tabular}

${ }^{(1)} \mathrm{Ha}: \operatorname{mean}($ diff $) \neq 0$

${ }^{(2)}$ Ha: $\operatorname{mean}($ diff $)>0$ 
Table A1-3

Dividend Yield by event year

This table reports the Dividend Yield for companies involved in a security class action and the peers group. The control group is a value-weighted portfolio of firms within the same 4-digit sic code (by event year). The bottom table report the paired t-test for the differences in event years. The null hypothesis is of zero difference in the means. The event year $t=0$ is the year in which the security class action suit was filed against the firm. The last two columns of the table present the results of the one and two-tailed mean-difference tests. $* * *, * *$ and $*$ denoted $1 \%, 5 \%$ and $10 \%$ significance respectively.

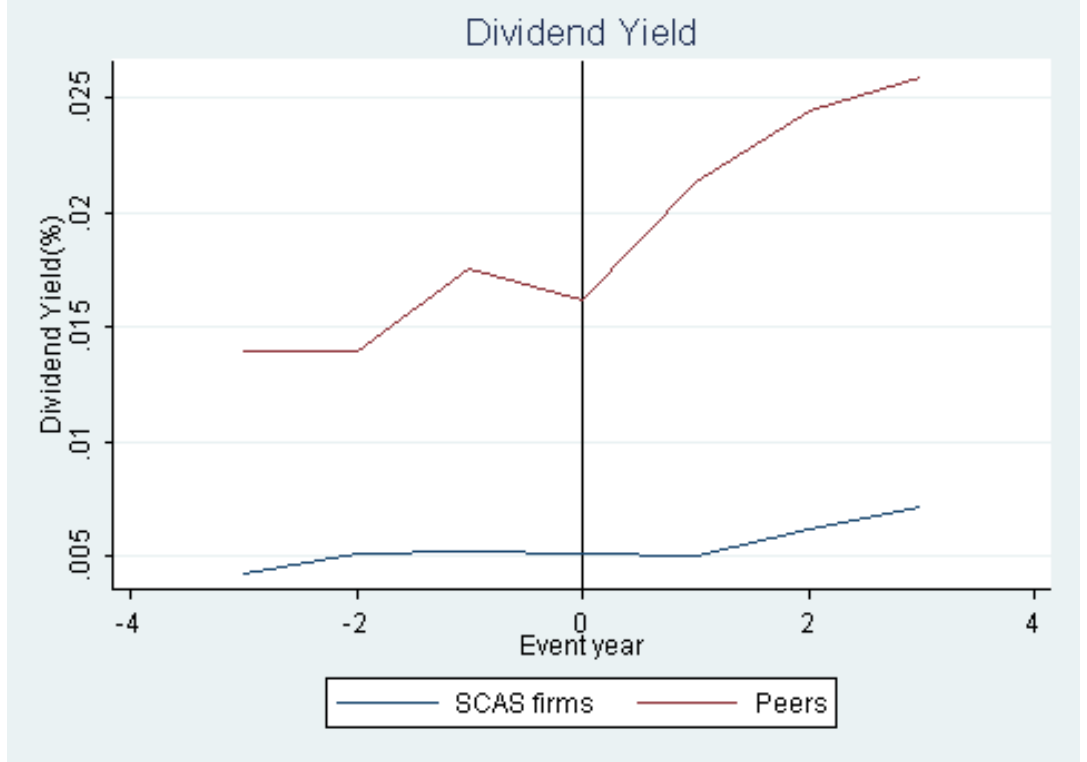

R\&D expenses yearly growth rate

\begin{tabular}{|c|c|c|c|c|c|c|}
\hline $\mathrm{t}$ & Variable & Obs & Mean & Mean(diff) & $\operatorname{Pr}(|\mathrm{T}|>|\mathrm{t}|)^{(1)}$ & $\operatorname{Pr}(\mathrm{T}<\mathrm{t})^{(2)}$ \\
\hline-3 & Dividend Yield SCAS firms & 683 & 0.004 & & & \\
\hline-3 & Dividend Yield PEERS firms & 683 & 0.014 & -0.010 & $0.000(* * *)$ & $0.000(* * *)$ \\
\hline-2 & Dividend Yield SCAS firms & 699 & 0.005 & & & \\
\hline-2 & Dividend Yield PEERS firms & 699 & 0.014 & -0.009 & $0.000(* * *)$ & $0.000(* * *)$ \\
\hline-1 & Dividend Yield SCAS firms & 661 & 0.005 & & & \\
\hline-1 & Dividend Yield PEERS firms & 661 & 0.018 & -0.013 & $0.000(* * *)$ & $0.000(* * *)$ \\
\hline 0 & Dividend Yield SCAS firms & 587 & 0.005 & & & \\
\hline 0 & Dividend Yield PEERS firms & 587 & 0.016 & -0.011 & $0.000(* * *)$ & $0.000(* * *)$ \\
\hline 1 & Dividend Yield SCAS firms & 521 & 0.005 & & & \\
\hline 1 & Dividend Yield PEERS firms & 521 & 0.020 & -0.016 & $0.000(* * *)$ & $0.000(* * *)$ \\
\hline 2 & Dividend Yield SCAS firms & 469 & 0.006 & & & \\
\hline 2 & Dividend Yield PEERS firms & 469 & 0.023 & -0.017 & $0.000(* * *)$ & $0.000(* * *)$ \\
\hline 3 & Dividend Yield SCAS firms & 390 & 0.007 & & & \\
\hline 3 & Dividend Yield PEERS firms & 390 & 0.026 & -0.019 & $0.000(* * *)$ & $0.000(* * *)$ \\
\hline
\end{tabular}

${ }^{(1)} \mathrm{Ha}$ : mean $($ diff $) \neq 0$

${ }^{(2)}$ Ha: $\operatorname{mean}($ diff $)<0$ 
Table IA2-1

Contagion effect analysis and the correlation of stock returns

This table reports the results of the regression: $Y_{j t}=\alpha_{j}+\beta_{j}(T)+\varepsilon_{j t}$; where, $Y_{j t}$ are either equity, debt or total security issuances, $\mathrm{T}$ is a trend variable that ranges from $\{1,6\}$ representing event years $\{-2,3\}$ , and $\varepsilon_{\mathrm{jt}}$ is the error term of the regression. . The amount of total -yearly- security offerings is measured as the sum of debt issuances and book equity issuances. Debt issuances are measured as the change in total assets minus change in book equity divided by total assets. Book equity issuances are measured as the change in book equity minus the change in balance sheet retained earnings, divided by total assets. The high/low correlation of returns dummy is defined as: 0 if correlations of returns (between SCAS and PEERS in the year preceding the filing) lies within the [1-50th] percentile and 1 if it lies within the [51-100]th percentile in the year before the filing of the SCAS.

\begin{tabular}{|c|c|c|}
\hline \multicolumn{3}{|c|}{ Dependent variable: Total security offerings } \\
\hline & High & Low \\
\hline Intercept & $0.138(* * *)$ & $0.101(* * *)$ \\
\hline $\mathrm{P}>|\mathrm{z}|$ & 0.000 & 0.000 \\
\hline Trend & $-0.012(* * *)$ & $-0.005(* * *)$ \\
\hline $\mathrm{P}>|\mathrm{z}|$ & 0.000 & 0.000 \\
\hline $\mathrm{N}$ & 197 & 198 \\
\hline Wald chi-square & 3746.4 & 705.71 \\
\hline $\mathrm{P}>$ chi-square & 0.000 & 0.000 \\
\hline \multicolumn{3}{|c|}{ Dependent variable: Equity issuances } \\
\hline & High & Low \\
\hline Intercept & $0.096(* * *)$ & $0.067(* * *)$ \\
\hline $\mathrm{P}>|\mathrm{z}|$ & 0.000 & 0.000 \\
\hline Trend & $-0.009(* * *)$ & $-0.003(* * *)$ \\
\hline $\mathrm{P}>|\mathrm{z}|$ & 0.000 & 0.000 \\
\hline $\mathrm{N}$ & 197 & 198 \\
\hline Wald chi-square & 4397.23 & 611.42 \\
\hline $\mathrm{P}>$ chi-square & 0.000 & 0.000 \\
\hline \multicolumn{3}{|c|}{ Dependent variable: Debt issuances } \\
\hline & High & Low \\
\hline Intercept & $0.049(* * *)$ & $0.036(* * *)$ \\
\hline $\mathrm{P}>|\mathrm{z}|$ & 0.000 & 0.000 \\
\hline Trend & $-0.005(* * *)$ & $-0.001(* * *)$ \\
\hline $\mathrm{P}>|\mathrm{z}|$ & 0.000 & 0.000 \\
\hline $\mathrm{N}$ & 197 & 198 \\
\hline Wald chi-square & 1533.82 & 93.26 \\
\hline $\mathrm{P}>$ chi-square & 0.000 & 0.000 \\
\hline
\end{tabular}




\section{Table IA2-2}

\section{Cumulative abnormal returns and contagion effect by type of allegation}

This table reports the cumulative abnormal returns of firms engaged in a corporate scandal (proxied by the filing of a security class action suit), and a value-weighted portfolio of the remaining firms with the same 4-digit sic code. The results are divided in two subsamples according to the type of allegations related to the security class action suit (accounting and non-accounting).

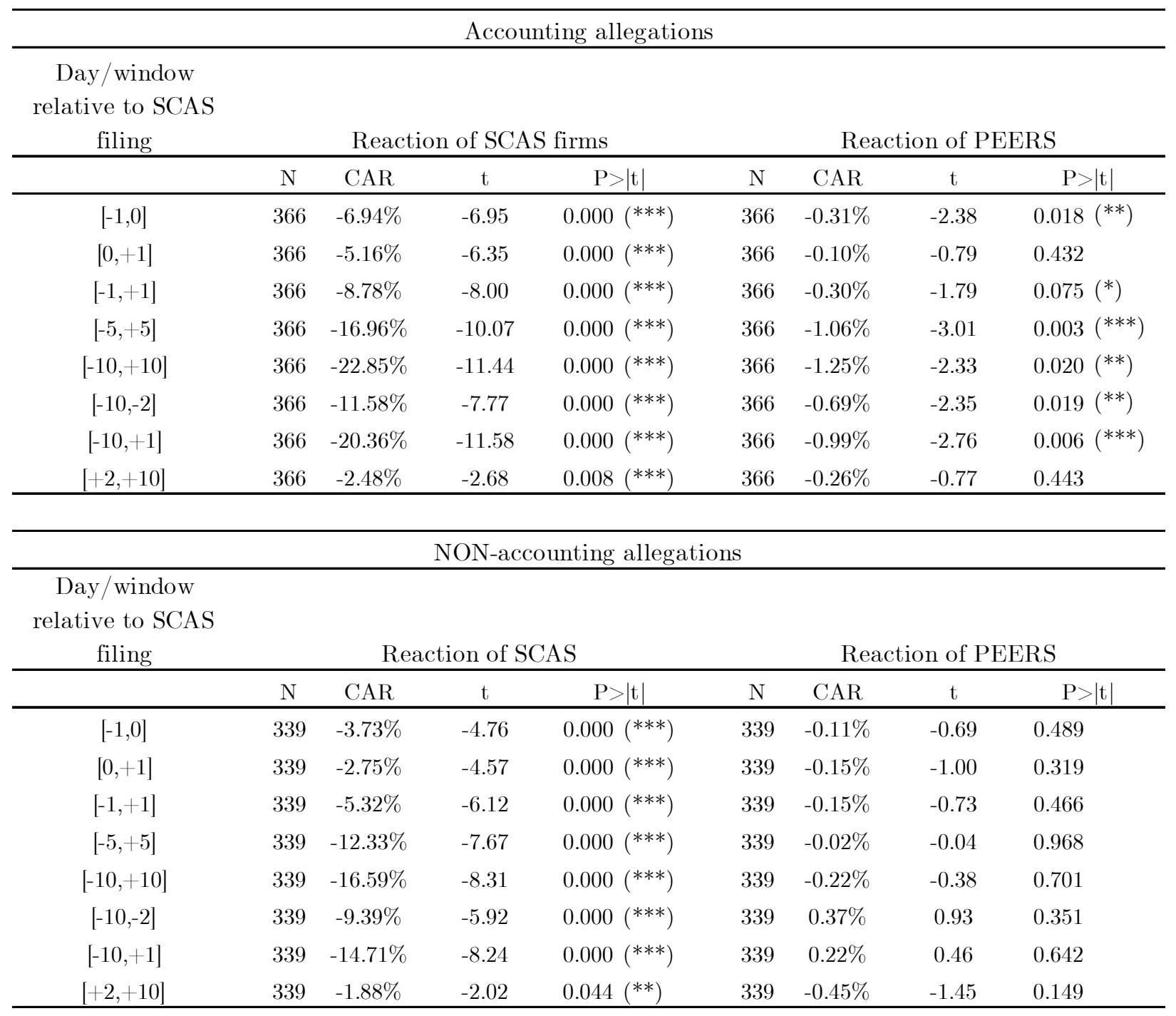

